\title{
The MAP Special Observing Period
}

\author{
P. Bougeault, ${ }^{*}$ P. Binder, ${ }^{+}$A. Buzzi," ${ }^{\prime}$ R. Dirks, ${ }^{@}$ R. Houze, ${ }^{\&}$ J. Kuettner, ${ }^{@}$ \\ R. B. Smith, ${ }^{* *}$ R. Steinacker, ${ }^{++}$and H. Volkert ${ }^{\# \#}$
}

\section{Objectives and context of MAP}

Intense weather over major mountain ranges such as the Alps brings a high cost to society in the form of floods, windstorms, and threats to aviation. The Mesoscale Alpine Programme (MAP; see Table 1 for a list of acronyms) is a measured response of the international atmospheric and hydrologic community to the challenge of improving the understanding and prediction of these events. It relies on intense international cooperation to assemble an alpine-scale dataset suitable to advance the basic knowledge and prediction techniques.

The following scientific objectives for MAP were published in the MAP Design Proposal (Binder and Schär 1996).

1a) To improve the understanding of orographically influenced precipitation events and related flooding episodes involving deep convection, frontal precipitation, and runoff.

1b) To improve the numerical prediction of moist processes over and in the vicinity of complex topog-

\footnotetext{
*Centre National de Recherches Météorologiques, Météo-France, Toulouse, France.

+MeteoSwiss, Zurich, Switzerland.

\#Istituto di Scienze dell'Atmosfera e dell'Oceano-CNR, Bologna, Italy.

${ }^{\circledR}$ Joint Office for Science Support, UCAR, Boulder, Colorado.

\&University of Washington, Seattle, Washington.

**Yale University, New Haven, Connecticut.

${ }^{++}$Meteorological Institute, University of Vienna, Vienna, Austria. \#Deutsches Zentrum für Luft und Raumfahrt, Oberpfaffenholen. Corresponding author address: Dr. Philippe Bougeault, Centre National de Recherches Météorologiques, Météo-France, 42, Avenue Gaspard Coriolis, 31057 Toulouse Cedex 01, France.

E-mail: philippe.bougeault@meteo.fr

In final form 8 September 2000.

(C)2001 American Meteorological Society
}

raphy, including interactions with land surface processes.

2a) To improve the understanding and forecasting of the life cycle of Foehn-related phenomena, including their three-dimensional structure and associated boundary layer processes.

2b) To improve the understanding of three-dimensional gravity wave breaking and associated wave drag in order to improve the parameterization of gravity wave drag effects in numerical weather prediction and climate models.

3) To provide datasets for the validation and improvement of high-resolution numerical weather prediction, hydrological, and coupled models in mountainous terrain.

These statements served as the basis for planning a large field experiment, the MAP Special Observing Period (MAP-SOP), which took place from 7 September to 15 November 1999. It was indeed recognized that only a major field program could provide the measurements needed to fully validate numerical weather prediction models for the simulation of intense weather in mountain areas. The present paper reports on this experiment which was the largest field program over the Alps since ALPEX in 1982. The links between MAP and previous experiments are further discussed in section $2 \mathrm{~b}$.

MAP involves a large number of committees and working groups, but the main permanent structures are the MAP Data Center and the Program Office, both created in 1995 by EUMETNET, the Network of European Weather Services for research and development. Their primary missions are to maintain an archive of the relevant data, facilitate intercomparison of numerical models, prepare the SOP (completed) and make SOP data available to a wide community. 
TABLE 1. Acronyms.

\begin{tabular}{|c|c|}
\hline AES & Atmospheric Environment Service (Canada) \\
\hline ALDIS & Austrian Lightning Detection and Information System \\
\hline ALPEX & Alpine Experiment \\
\hline ARAT & Avion de Recherche et de Télédétection (France) \\
\hline BOLAM & Bologna Limited Area Model (Italy) \\
\hline CETP & Centre des Environnements Terrestres et Planétaires (France) \\
\hline CIRES & Cooperative Institute for Research in Environmental Science (United States) \\
\hline CNR & Consiglio Nazionale delle Richerche (Italy) \\
\hline CNRM & Centre National de Recherches Météorologiques (France) \\
\hline CNRS & Centre National de la Recherche Scientifique (France) \\
\hline COAMPS & Coupled Ocean Atmosphere Mesoscale Prediction System (United States) \\
\hline $\mathrm{COC}$ & Coordination and Operations Center (Bad Ragaz, Switzerland) \\
\hline CRA & Colorado Research Associates (United States) \\
\hline CSIM & Centro Sperimentale per l'Idrologia e la Meteorologia (Italy) \\
\hline CVB & Constant volume balloons \\
\hline DIAL & Differential absorption lidar \\
\hline DLR & Deutsches Zentrum für Luft und Raumfahrt (Germany) \\
\hline DOW & Doppler-on-Wheels Radar (NCAR/University of Oklahoma) \\
\hline DRI & Desert Research Institute (United States) \\
\hline DWD & Deutscher Wetterdienst (Germany) \\
\hline ECMWF & European Centre for Medium-Range Weather Forecasts \\
\hline ETH & Swiss Federal Institute of Technology (Zurich, Switzerland) \\
\hline EUMETNET & European Meteorological Network \\
\hline GOP & General observing period \\
\hline GPS & Global Positioning System \\
\hline GTS & Global Transmission System \\
\hline GWB & Gravity wave breaking \\
\hline HERA & Heavy rain on the Alps \\
\hline IGN & Institut Géographique National (France) \\
\hline IMGW & Institut für Meteorologie und Geophysik, University of Vienna \\
\hline IMK & Institut für Meteorologie und Klimaforschung, Forschungszentrum Karlsruhe \\
\hline INSU & Institut National des Sciences de l’Univers (France) \\
\hline IOP & Intensive observing period \\
\hline ISAO & Istituto di Scienze dell'Atmosfera e dell'Oceano (Bologna, Italy) \\
\hline JOSS & Joint Office for Science Support (United States) \\
\hline LA & Laboratoire d'Aérologie (France) \\
\hline LMD & Laboratoire de Météorologie Dynamique (France) \\
\hline
\end{tabular}

The SOP was funded by many European and North American weather services and science agencies. A list of agencies is given in Table 2. Some additional funding for the preparation was provided by the European Union, under the HERA and RAPHAEL projects. The European Union also supported some operations of the Fokker and Falcon aircraft through the STAAARTE training program. After the creation of the World Weather Research Program by the World Meteorological Organization in 1998, MAP was incorporated in this new action as the first of a series of "research and development projects." Finally, the MAP-SOP coincided in time with another field experiment, organized by the European Composite Observing System
(EUCOS) program of EUMETNET. This provided ample additional radiosonde measurements at selected sites and measurements by commercial airplanes from all major European airports.

\section{Organization of the SOP}

\section{a. The scientific projects}

The SOP was organized into eight scientific projects, referred to as $\mathrm{P} 1$ to $\mathrm{P} 8$, which were to some extent in competition for access to the main facilities. We will give here a brief outline of these projects. A complete list of detailed scientific questions can be 
Table 1. Continued.

\begin{tabular}{|c|c|}
\hline LMTA & Lago Maggiore Target Area \\
\hline LSEET & Laboratoire de Sondage de l'Environnement Electromagnétique Terrestre (Toulon, France) \\
\hline MAP & Mesoscale Alpine Programme \\
\hline $\mathrm{MC} 2$ & Modèle Mésoéchelle Compressible Communautaire (Canada) \\
\hline MDC & MAP Data Center (Zurich, Switzerland) \\
\hline MeteoSwiss & Swiss Meteorological Service \\
\hline Météo-France & French Meteorological Service \\
\hline MIM & Meteorologisches Institut, Universitat München \\
\hline MM5 & Mesoscale Model Version 5 (United States) \\
\hline MNC & MAP Network Center (Zurich, Switzerland) \\
\hline MOC & MAP Operations Center (Innsbruck, Austria) \\
\hline MPO & MAP Project Office (Zurich, Switzerland) \\
\hline MST & Mission selection team \\
\hline NASA & National Aeronautics and Space Administration (United States) \\
\hline NCAR & National Center for Atmospheric Research (United States) \\
\hline NOAA & National Oceanic and Atmospheric Administration (United States) \\
\hline NRL & Naval Research Laboratory (United States) \\
\hline NSF & National Science Foundation (United States) \\
\hline OPRA & Orographic Precipitation Radar (United States) \\
\hline PBL & Planetary Boundary Layer \\
\hline PNNL & Pacific Northwest National Laboratory (United States) \\
\hline POC & Project Operations Center (Milan, Italy) \\
\hline PSI & Paul Scherrer Institute (Switzerland) \\
\hline PV & Potential vorticity \\
\hline PYREX & The Pyrenean Experiment \\
\hline RAPHAEL & Runoff and Atmospheric Processes for Flood Hazard Forecasting and Control \\
\hline RHI & Range-height indicator, radar vertical cross section \\
\hline SMR & Servizio Meteorologico Regionale (Bologna, Italy) \\
\hline SOP & Special observing period \\
\hline STAAARTE & Scientific Training and Access to Aircraft for Atmospheric Research Throughout Europe \\
\hline TWL & Transportable Wind Lidar (France) \\
\hline UCAR & University Corporation for Atmospheric Research (United States) \\
\hline UGM & Ufficio Generale per la Meteorologia (Italy) \\
\hline UIV & Umwelt Institut, Vorarlberg \\
\hline UKMO & The Met. Office (United Kingdom) \\
\hline WMO & World Meteorological Society \\
\hline ZAMG & Zentralanstalt für Meteorologie und Geodynamik, Vienna \\
\hline
\end{tabular}

found in the MAP Science Plan (Bougeault et al. 1998).

Project P1: Orographic precipitation mechanisms. This project addressed the basic mechanisms of production or enhancement of precipitation by topography. It involved studies of the small-scale dynamics of precipitating systems, including convective systems and their interaction with the topography, and studies of the detailed growth mechanisms of precipitation particles.

Project P2: Incident upper-tropospheric PV anomalies. This project focused on the dynamics of the large potential vorticity anomalies approaching the Alps from the west at the tropopause level, also called PV streamers. The role of these anomalies as precur- sors of severe precipitation in the Alps was investigated, along with their modification by the diabatic heating due to the Alpine precipitation and the significance of small-scale structures seen on water vapor satellite images.

Project P3: Hydrological measurements and flood forecasting. This project explored the near-real-time forecasting capabilities of hydrological flood models, forced by special precipitation measurements or by mesoscale meteorological models. The testing of soil moisture monitoring techniques, the significance of soil moisture initial conditions, and the impact of information on water storage in power company reservoirs were particularly examined. 
TABLE 2. Funding agencies for the MAP-SOP.

\begin{tabular}{ll} 
Austria & $\begin{array}{l}\text { Federal Ministries of Science and Environment } \\
\text { National Science Foundation } \\
\text { Austrocontrol } \\
\text { Central Institute for Meteorology and Geodynamics }\end{array}$ \\
Canada & Atmospheric Environment Service \\
\hline European Union & STAAARTE Program \\
France & $\begin{array}{l}\text { Centre National de la Recherche Scientifique } \\
\text { Météo-France } \\
\text { Electricité de France } \\
\text { Centre National d'Etudes Spatiales }\end{array}$ \\
\hline
\end{tabular}

Deutsches Zentrum für Luft und Raumfahrt
Deutscher Wetterdienst
Deutsche Forschungsgemeinschaft
Forschungszentrum Karlsruhe

$\begin{array}{ll}\text { Italy } & \text { National Research Council } \\ & \text { Ufficio Generale per la Meteorologia }\end{array}$

$\begin{array}{ll}\text { Switzerland } & \text { MeteoSwiss } \\ & \text { Swiss Federal Institute of Technology } \\ & \text { Swiss National Science Foundation } \\ & \text { Swiss Army, Joint Meteorological Services } \\ & \text { Paul Scherrer Institute }\end{array}$

United Kingdom The Met. Office

United States National Science Foundation

National Oceanic and Atmospheric Administration

Naval Research Laboratory

National Aeronautics and Space Administration

Project P6: Three-dimensional gravity wave breaking. This project sought answers to the basic questions regarding the creation of clear-air turbulence by breaking gravity waves, such as the space and time distribution of GWB, the predictability of gravity waves by mesoscale models, the vertical distribution of momentum fluxes in the presence of breaking gravity waves, and the associated potential vorticity generation. It also used new experimental observational strategies, combining remote sensing and in situ techniques.

Project P7: Potential vorticity banners. This project investigated the high-resolution structure of the Alpine wake at or below mountaintop level. Numerical models suggest that the wake is organized in welldefined potential vorticity banners, extending downstream over several hundred kilometers. The existence and the crossstream spatial scale of these flow structures were documented.

Finally, Project P8: Structure of the planetary boundary layer over steep orography. This project sought answers to a number of broad questions on the

Project P4: Dynamics of gap flow. This project investigated the three-dimensional velocity distribution at the Brenner Pass and within the Wipp valley, and its time and space variability in relation to the flow above mountaintop. The data address some key questions of stratified fluid dynamics, such as the possible formation of a hydraulic jump downstream of the gap, and the consequences of this jump.

Project P5: Nonstationary aspects of foehn in a large valley. This project addressed the fourdimensional variability of the foehn flow in the Rhine valley. It investigated several dynamical processes that determine the spatial extension and time variations of the foehn, such as the modification of the air mass by radiation, and the interaction with the upperlevel flow. structure of the orographic PBL, such as its depth and evolution, the three-dimensional distribution of turbulent fluxes within a steep valley, the interaction of PBL turbulence with the local winds, and the exchange of air mass and atmospheric constituents between the PBL and the free troposphere.

\section{b. Links with ALPEX and PYREX}

MAP greatly benefited from the impetus, experience, and results of previous international field programs on orographic flows, mainly ALPEX (1982) and PYREX (1990). ALPEX (e.g., Kuettner 1986) allowed fundamental advances in understanding how air flows over and around the Alps. It also provided excellent observations of lee cyclogeneses and downslope winds. PYREX, a study of the momentum 
budget of the flow across and around the Pyrenees (e.g., Bougeault et al. 1997) allowed great progress of the orography representation in numerical models. Several of the scientific objectives of MAP appear as an expansion of the objectives of these previous programs: for instance the design of Projects P6, P7, and P8 was largely influenced by ALPEX and PYREX findings on gravity waves, the structure of the mistral and tramontana regional winds, and the early observations of turbulence in the vicinity of a major mountain range. But many MAP objectives had not been addressed at all in previous programs. The heavy orographic rainfall events (P1), their connection with the upper troposphere (P2), and their hydrological consequences (P3) were not part of ALPEX or PYREX objectives. The gap flow (P4) and foehn studies (P5) of MAP were developed at much finer time and space scales than could be achieved at the time of ALPEX and PYREX. New observing technologies, the progress of high-resolution numerical modeling, and a much broader international participation have made MAP a completely new program.

\section{c. Target areas and operations centers}

A list of available measurement systems during the SOP is provided in Table 3. In terms of ground systems, MAP was probably the largest field experiment ever conducted in Europe. The field activities were concentrated in three target areas (see Fig. 1). The Lago Maggiore Target Area (LMTA) was the main focus of Projects P1 and P3 (so-called Wet-MAP), as well as part of P8. The Brenner Target Area was the focus for Project P4, and the Rhine valley Target Area was the focus for Project P5 and part of P8. The remaining Projects (P2, P6, and P7) were not linked to specific geographical areas, as they relied mainly on aircraft measurements.

The MAP Operations Center (MOC), hosted jointly by Austrian scientific institutions and weather services at the Innsbruck airport, was the main center of decision, and the main concentration point of MAP scientists during the field phase. The MOC selected the intensive observation periods (IOPs) and the flight missions, and negotiated flight clearances with all air traffic control (ATC) centers involved in MAP missions. It also coordinated the activities of the Brenner Pass Target Area. The NCAR Electra, NOAA P-3, and UKMO C130 aircraft were based at the MOC, while the DLR Falcon and Dornier 228 operated from their home base in Oberpfaffenhofen, $90 \mathrm{~km}$ north of Innsbruck, Austria.
The activities of the Lago Maggiore Target Area were coordinated at the Project Operations Center (POC), hosted by the Italian Meteorological Service in the Regional Meteorological Center at MilanoLinate military airport. The French Merlin IV and Fokker 27 aircraft were based at the POC. The radar data from the southern side of the Alps were concentrated at the POC and used to construct a real-time composite of the precipitation areas on the southern side of the Alps. This was used by MOC scientists to guide the MAP aircraft toward areas of greatest interest, in close collaboration with the regional air traffic control center in Milan, Italy. It must be stressed that the LMTA is one of the most crowded air traffic areas in Europe. Overall, the POC played a unique role in making aircraft missions on the southern side of the Alps possible and successful.

The activities of the Rhine valley Target Area were coordinated from the Coordination and Operations Center (COC), hosted by the Swiss Army and ETH in Bad Ragaz, Switzerland. The Swiss Dimona aircraft was based in Altenrhein, near the Lake Constance at the estuary of the Rhine River.

The three operations centers remained in close contact via phone, Internet, and fax during the whole field experiment. Joint briefings were held every day for weather, flight proposals, decisions, and the preparation of joint missions. More information on the operations schedule and the decision-making process can be found in the MAP Implementation Plan (Binder et al. 1999).

\section{d. Special meteorological products}

Forecasts for MAP operations were provided by an international team of 25 forecasters working in shifts at the MOC in Innsbruck. They relied on a variety of model products, satellite, and radar pictures to issue daily forecasts tailored to the needs of mission planning. Forecasting support was also available at the POC, especially for nowcasting.

The national and regional meteorological services of the Alpine countries made an outstanding effort to respond to the data and forecast needs of MAP. This is illustrated here by the network of operational and research radars (Fig. 2) and by the network of upper air measurements by radiosondes and wind profilers (Fig. 3). Also impressive was the real-time exchange of surface data from automated stations that outnumbered normal WMO requirements by a factor of 10 or more. All these data are already available from the MDC without any restriction. 
TABLE 3. Main experimental facilities available during the SOP.

\begin{tabular}{|c|c|c|c|}
\hline Target area & Location & Facility & Institution \\
\hline \multirow[t]{8}{*}{ Aircraft } & Innsbruck & Electra & NCAR \\
\hline & & & NOAA \\
\hline & & C-130 & UKMO \\
\hline & Oberpfaffenhofen & Falcon & DLR \\
\hline & & Dornier 228 & DLR \\
\hline & Milan & Merlin IV & Météo-France \\
\hline & & Fokker 27 ARAT & CNRS/IGN/CNES/Météo-France \\
\hline & Locarno/Altenrheim & Dimona & Metair \\
\hline \multirow[t]{14}{*}{ Lago Maggiore } & Vergiate & S-Pol Doppler radar, & NCAR \\
\hline & Novarra & $\begin{array}{l}\text { Ronsard Doppler radar, } \\
\text { Disdrometer }\end{array}$ & CETP \\
\hline & Monte Lema & Doppler radar & MeteoSwiss \\
\hline & Toce and Ticino valleys & DOW Doppler radar & $\begin{array}{l}\text { University of Oklahoma, Princeton } \\
\text { University, and }\end{array}$ \\
\hline & & OPRA Radar & University of Washington \\
\hline & Macugnaga & $\begin{array}{l}\text { Vertical Doppler radar, } \\
\text { disdrometer }\end{array}$ & ETH \\
\hline & Locarno Monti & Vertical Doppler radar & IMK \\
\hline & Lonate Pozzolo & UHF and VHF wind profiler & Météo-France \\
\hline & Pallanza & Lidar & IFA-CNR \\
\hline & 10 sites in Po valley & $\begin{array}{l}\text { Sodars, UHF radars, PBL } \\
\text { stations, microbarograph, radio } \\
\text { soundings }\end{array}$ & $\begin{array}{l}\text { CNR, ENEL, JRC Ispra, } \\
\text { Universities of Alessandria, Brescia, } \\
\text { Torino, Genova, etc. }\end{array}$ \\
\hline & Riviera valley & PBL instrumentation & ETH \\
\hline & Toce valley & Soil moisture and PBL & $\begin{array}{l}\text { Universities of Brescia, Milan, } \\
\text { Modena, CNR }\end{array}$ \\
\hline & Ispra & CVB, atmospheric electricity & LA \\
\hline & Milan (POC) & Integrated water vapor by GPS & IGN/INSU \\
\hline \multirow[t]{3}{*}{ Rhine valley } & Vilters & TWL scanning lidar & LMD \\
\hline & Trübbach & Vertical aerosol lidar & University of Neuchatel \\
\hline & Rankwell & UHF and RASS & IMK \\
\hline
\end{tabular}


TABle 3. Continued.

\begin{tabular}{|c|c|c|c|}
\hline \multirow[t]{2}{*}{ Target area } & Location & Facility & \multirow{2}{*}{$\begin{array}{l}\text { Institution } \\
\text { MeteoSwiss }\end{array}$} \\
\hline & Julier Pass & $\begin{array}{l}\text { VHF profiler, sodar, radio } \\
\text { sounding, surface station }\end{array}$ & \\
\hline & Hoherkasten & Video cameras & MeteoSwiss \\
\hline & Several sites & PBL instrumentation, sodars & $\begin{array}{l}\text { IMGW, MeteoSwiss, ZAMG, PSI, } \\
\text { ETH, UIV } \\
\text { MIM }\end{array}$ \\
\hline & 7 sites & Radio-sounding stations & Swiss army, IMGW \\
\hline & Sevelen & $\begin{array}{l}\text { Scintillometers, } \\
\text { CVB tracking stations }\end{array}$ & $\begin{array}{l}\text { PSI } \\
\text { MeteoSwiss, LA }\end{array}$ \\
\hline \multirow[t]{4}{*}{ Brenner } & Gedeir & Scanning lidar & NOAA/ETL \\
\hline & Several sites & Surface stations & $\begin{array}{l}\text { Universities of Innsbruck, Modena, } \\
\text { München, PNNL }\end{array}$ \\
\hline & Several sites & Microbarographs & University of Leeds \\
\hline & Several sites & Sodars, UHF, radio soundings & $\begin{array}{l}\text { ZAMG, Universities of Modena, } \\
\text { Innsbruck, Washington }\end{array}$ \\
\hline
\end{tabular}

In this respect, an interesting consequence of MAP was noted in Italy, where the SOP led to the first operational cooperation (exchange of data and forecasters) among the several existing local services and the National Service operated by the Italian Air Force.

Table 4 summarizes the major sets of observations and forecasting products that were transmitted in real time (via the GTS and the Internet) to the MAP information network. In order to ease the use of the abundant mass of information, an effort was undertaken to standardize the look and feel of the products.

Several special products were also available to MAP forecasters and scientists during the SOP. Rapid scans (5 min) of the Meteosat-6 standby satellite over the Alpine region (see Fig. 4) were activated by EUMETSAT for 24-h periods, on request from the MOC (Levizzani 1998). These covered most of the IOPs. The success of this operation lead to the conclusion that a similar service could be opened on a more routine basis in the near future. A midlatitude and a tropical window are being considered. This may become an important and rapid consequence of the MAP-SOP. A special "alpine radar composite" was produced by DLR with data from all operational radars around the Alps. It was made available through the Internet within 30 min from observations. By special agreement of most operational atmospheric electricity networks, enhanced data on lightning were transmitted in real time to ALDIS (Vienna, Austria). These were used to compute more precise locations of lightning strikes all over the Alps by combining information from the national networks. This information was displayed on the operational Austrian system in the MOC and was accessible to MAP forecasters.

Finally, a special numerical weather prediction suite was run to provide very high resolution forecasts at the Alpine scale. The mesoscale Canadian AES MC2 model was run at the horizontal resolution of $3 \mathrm{~km}$ and forced by initial and boundary conditions from the operational model of MeteoSwiss. The model was run every night at the Swiss Center for Scientific Computing in Manno (Switzerland) for the period 2100 UTC of the previous day to 0400 UTC (i.e., a time window of $27 \mathrm{~h}$ ). Detailed forecasts of precipitation, wind, turbulence, and potential vorticity were 


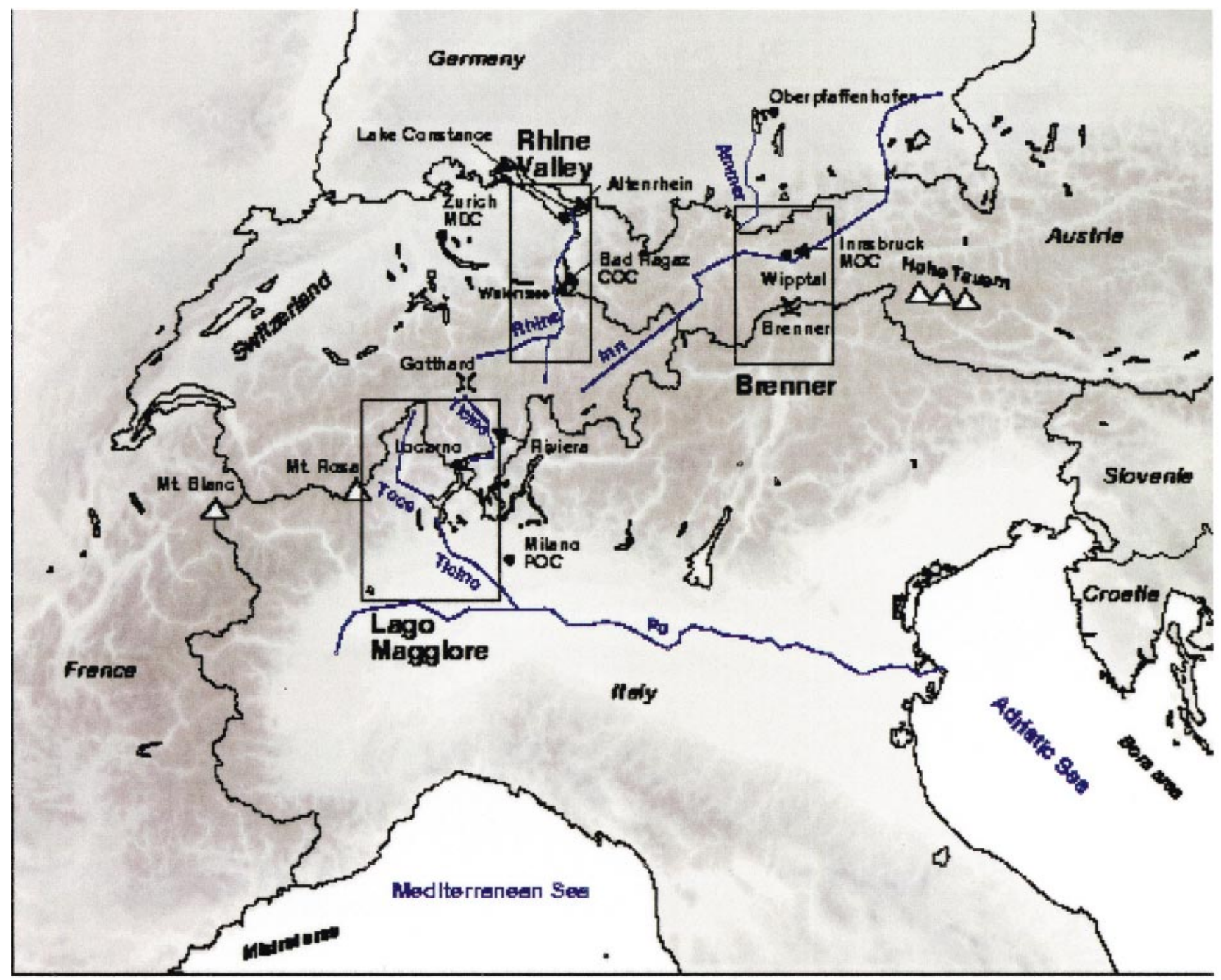

FIG. 1. Main geographic features for the SOP.

available on horizontal and vertical cross sections of interest, and were used by mission scientists to optimize the flight plans of the day. The detailed verification of MC2 forecasts was a central objective of several scientific projects. An extensive report on MC2 results has been prepared by R. Benoit et al. (2000, personal communication).

In addition, various model runs (e.g., BOLAM, COAMPS, MM5, MC2 at lower resolution, etc.) were made available to MAP forecasters and scientists through the Internet.

\section{e. Summary of operations}

The SOP benefited from excellent weather conditions. After an initial anticyclonic period from 7 to 15 September, the Alps came under the influence of a series of perturbations moving from west to east, most of them bringing active fronts and convection into the LMTA. Following a classic pattern, the fronts were preceeded by a brief period of southwesterly flow leading to foehn conditions on the northern side of the Alps, and some of them were followed by northwesterly flow, favoring the onset of PV banners. The anticyclonic conditions returned around mid-October for 10 days. The last month of the SOP had a large variety of situations, most of which were pertinent to at least one of the projects, leading to a very active schedule of IOPs. In summary, 17 IOPs were conducted, totaling 42 days of activity. All available resources (in terms of sondes, flight hours, etc.) were exhausted by the end of the SOP. The operations are summarized in Table 5. It is clear from the table that most projects fully reached their objectives. Figure 5 shows that the available aircraft resources were utilized by the various projects according to the preagreed plans. 
The statistical evaluation shows that the year 1999 was a very good year relative to the frequency and distribution of MAP-relevant weather events. All phenomena occurred more frequently than expected relative to the average of the last 10 years. Foehn in the Rhine valley and gap flow events occurred $40 \%$ and $15 \%$ more frequently than the average. The PV streamers, gravity waves, and PV banners occurred at more than twice the average frequency. Only PV banner situations with a northerly flow occurred slightly less frequently than the average. The number of 17 IOPs corresponds exactly to the maximum number that would have been possible during the 10 previous years. The last equally favorable year was 1993 . Hence we can state that the 1999 SOP season offered an outstanding opportunity that could be expected only once every five years.

\section{Preliminary experimental results}

\section{a. Orographic precipitation mechanism}

To accomplish the scientific objectives of $\mathrm{P} 1$, a nested observational strategy was designed. The networks of operational radars in the Alpine region provided a rich background (see Fig. 2). In the LMTA, more detailed observations were provided by seven ground-based research radars. The French Ronsard radar and the Swiss Monte-Lema radar provided dual-Doppler data, and the U.S. S-Pol radar increased the resolution of these measurements and mapped the microphysical structure within the dual-Doppler array through dual-polarization measurements. Three small specialized radars provided vertical profiles of reflectivity (the U.S. S-band OPRA, the Swiss $X$ band, and the German $\mathrm{K}$ band). The U.S. Doppleron-Wheels (DOW, Wurman et al. 1997) obtained Doppler radial velocity measurements of the winds in the Toce and Ticino River valleys to indicate how the flow is modified on the valley scale. Two French wind profilers were installed in the LMTA and continuously monitored the wind field throughout the SOP, providing detailed upstream conditions for orographic rain events by southerly flow. Finally, many Italian PBL measurements were made in the LMTA in support of this project, including sodars, one tethered balloon, surface energy balance stations, one water vapor lidar, one special sounding station, and a microbarograph network. Whenever possible, aircraft missions were flown over this highly instrumented region in coordination with the ground-based radars. The P-3 and Electra provided airborne Doppler measurements and cloud physics sampling in specific subregions of the area covered by the radars. The Fokker, carrying the LEANDRE 2 lidar (Flamant et al. 2000), supplemented these measurements with low-level upstream temperature, moisture, wind, and PBL height data. The Merlin acquired in situ microphysical measurements in the cloud systems of the Po valley that will be very useful to check the effectiveness of the polarimetric retrieval techniques. The Merlin and Fokker also conducted two missions in the Po valley to map the surface fluxes of sensible and latent heat prior to interesting rain evens.

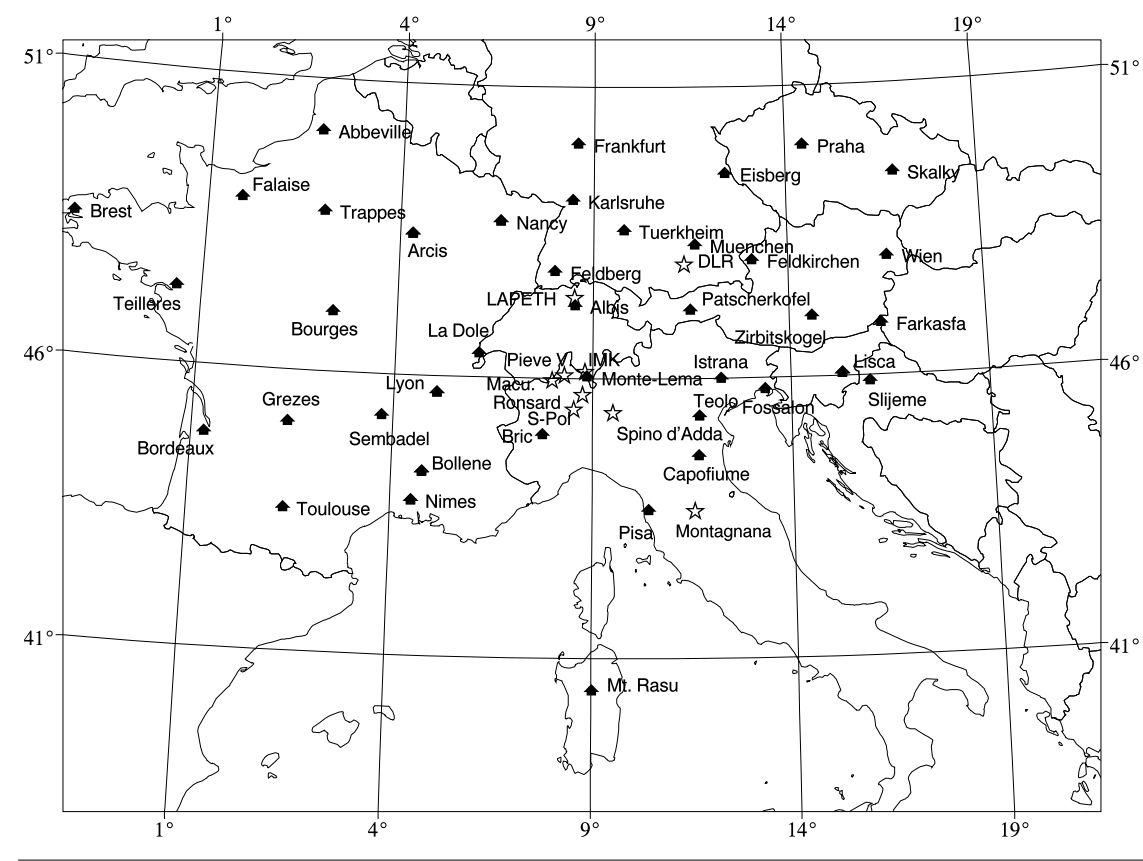

300 0 300 600 Kilometers

Experimental Radar network

- Operational Radar network

FIG. 2. Operational and research radars in the greater MAP region during the SOP. 
The LMTA experienced heavy precipitation on several occasions (see Table 5), due to conditionally unstable southerly flow originating from the Mediterranean. An example is provided in Figs. 6 and 7, from IOP5. Figure 6a shows the dual-Doppler winds at the $2.5-\mathrm{km}$ level during a time when the heavy rain was falling over the Lago Maggiore (Italy). These data were retrieved in real time from the Ronsard and Monte-Lema radars (Chong et al. 2000). The detailed topography in Fig. 6a shows how the Alpine barrier forms an arc around the LMTA with the low, flat Po valley lying to the south. As the large-scale flow from the Po valley approached from the southwest it was apparently deflected by the barrier on the eastern side of the arcing terrain such that it turned to a more southerly direction. On the western side of the arc, the flow retained its southwesterly direction as it ran along the southwest-northeast-oriented foothills of the Alps. A confluence area can be noted in the region of the Monte-Lema and DOW radars. Figure 6b shows the horizontal pattern of radar reflectivity coincident with the wind pattern in Fig. 6a. A line of convective cells

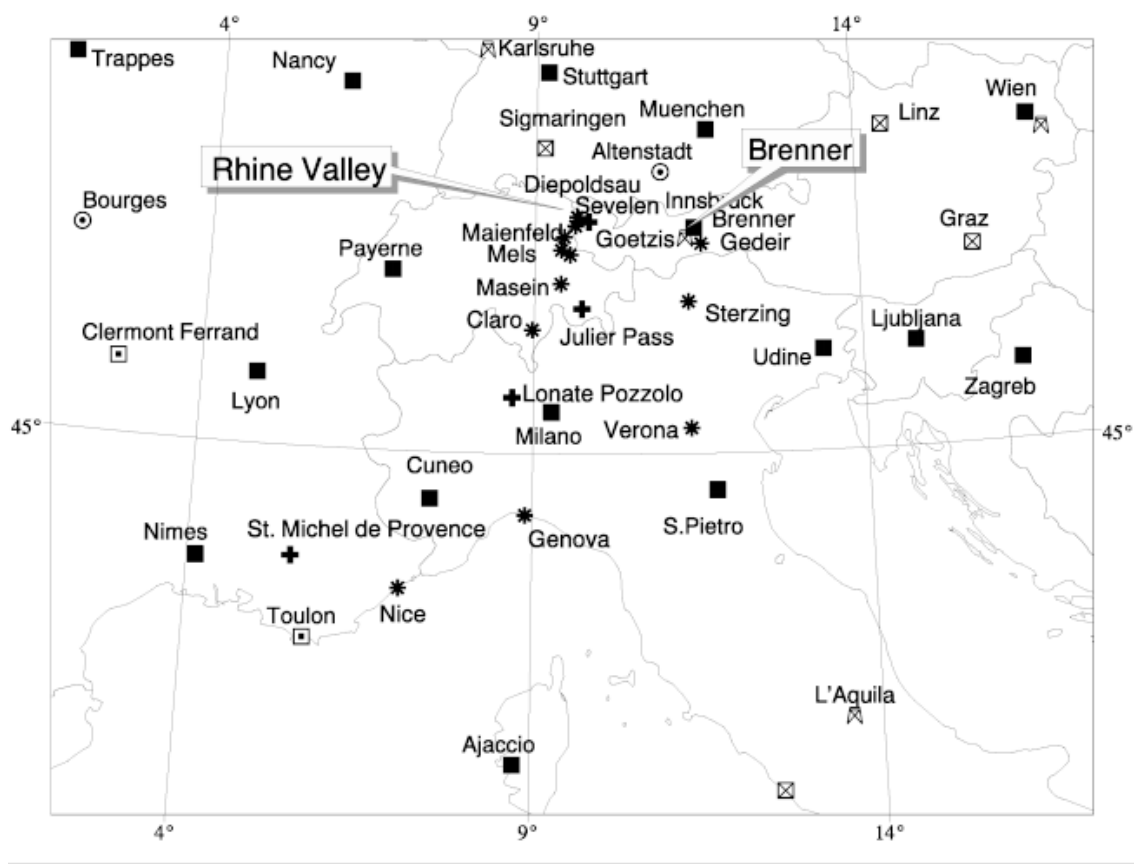

300 0 300 600 Kilometers

* Experimental Radiosounding stations during MAP SOP

- Stations with enhanced Radiosounding during MAP SOP

+ Experimental Wind profiler

ه Operational CWINDE99 $1290 \mathrm{MHz}$

- Operational CWINDE99 $50 \mathrm{MHz}$

$\otimes$ PTU Radiosounding stations

$\odot$ PILOT Radiosounding station

FIG. 3. Radiosonde and wind profilers networks in the MAP region during the SOP. occurred in the region of confluence of the wind field. This line persisted for many hours, and the cumulative effect of the cells was enormous $(280 \mathrm{~mm}$ measured by one rain gauge for this day). Not far from the DOW radar (position dow2 in Fig. 6a), the excessive rainfall caused severe damage and one fatality. Figure 6c shows data along a radial cross section extending north-northeastward from the S-Pol radar, through the line of cells and across the location of the DOW radar. This cross section, which lies quasiparallel to the flow at the $2.5-\mathrm{km}$ level, shows the profile of the topography, the horizontal airflow, and the radar reflectivity. Cells of high reflectivity (up to $48 \mathrm{dBZ}$ ) appear over the lower foothills. The maximum values were confined to levels below about $4 \mathrm{~km}$. Weaker echoes extended up to 10-12 km. This echo structure was typical of MAP heavy rainstorms. Persistent upslope flow of the lower-tropospheric conditionally unstable Mediterranean air released rainfall in these modest cells that were forming repeatedly over the foothills for many hours.

While the general mesoscale flow in the lower troposphere was rapidly approaching the Alpine barrier and rising over the foothills, the flow within individual river valleys exhibited a much different behavior in the lowest kilometer of the atmosphere. During all of the major rain events in MAP, the DOW radar made observations in either the Ticino (through IOP5) or Toce River (after IOP5) valleys. In all cases, downvalley flow occurred in the lowest 1-2 km, with upslope flow at higher levels. This is one of the most interesting and consistent findings of P1.

The S-Pol radar also provided a suite of polarimetric radar variables that are functions of the returned power and phase of the radar signal at horizontal and vertical polarization. These parameters indicate microphysical properties of the precipitation particles producing the radar echoes. One of the objectives of MAP was to obtain polarimetric radar data to indicate 
TABLE 4. Real-time products providers during the SOP.

\begin{tabular}{lccllll}
\hline \hline Service & Fcsters & RS & Surface data & Radars & NWP & other \\
\hline ZAMG (Austria) & 3 & 72 & TAWES & $\begin{array}{l}\text { CERAD } \\
\text { composite }\end{array}$ & $\begin{array}{l}\text { ECMWF and } \\
\text { ALADIN-LACE }\end{array}$ & Visualization system \\
& & & & models
\end{tabular}

\begin{tabular}{|c|c|c|c|c|c|c|}
\hline Military WS (Austria) & 1 & & & & & \\
\hline Austrocontrol (Austria) & 2 & 102 & & A composite & & ALDIS (lightning) \\
\hline UGM (Italy) & 1 & 280 & & $\begin{array}{l}\text { North Italian } \\
\text { radars }\end{array}$ & & \\
\hline CSIM (Italy) & & & $\begin{array}{l}\text { Automatic } \\
\text { stations }\end{array}$ & $\begin{array}{l}\text { SINA- } \\
\text { composite }\end{array}$ & & \\
\hline Regional Services (Italy) & 7 & 280 & $\begin{array}{l}\text { Automatic } \\
\text { stations }\end{array}$ & Yes & & \\
\hline MeteoSwiss & 2 & 72 & ANETZ, ENET & $\begin{array}{l}\mathrm{CH} \text { composite, } \\
\text { Monte Lema }\end{array}$ & $\begin{array}{l}\text { Swiss Model } \\
14 \mathrm{~km}\end{array}$ & Meteosat, NOAA \\
\hline Météo-France & 4 & 336 & 1-h synoptic & F composite & & Météorage (lightning) \\
\hline DWD (Germany) & 2 & 144 & 1-h synoptic & D composite & $\begin{array}{l}\text { Lokal Modell } \\
7 \mathrm{~km}\end{array}$ & \\
\hline
\end{tabular}

$\begin{array}{ll}\text { DLR (Germany) } & \text { Alpine } \\ \text { composite }\end{array}$

AES/RPN (Canada) 1

MC2 $3 \mathrm{~km}$

(run at

SCSC Manno,

Switzerland)

$\begin{array}{lccc}\text { Croatia } & 2 & 72 & 1 \text {-h synoptic } \\ \text { Slovenia } & 2 & 102 & 1 \text {-h synoptic } \\ \text { INM (Spain) } & 72 & 1 \text {-h synoptic Barcelona }\end{array}$

UKMO (UK)

CWINDE profilers

NRL and NWS (US)

1

COAMPS

the microphysics of the precipitation processes in the context of orographically influenced mesoscale and valley-scale airflow. Figure 7 shows results of applying the particle identification algorithm of Vivekanandan et al. (1999) to polarimetric data obtained during the IOP5 rainstorm exhibited in Fig. 6.
The various colors in Fig. 7b indicate the categories of particle type identified by the algorithm. The Vivekanandan et al. (1999) algorithm was run side by side throughout MAP with a simpler algorithm (Zeng 1999), which uses the thresholds and only a few broader but more certain particle-type categories. 


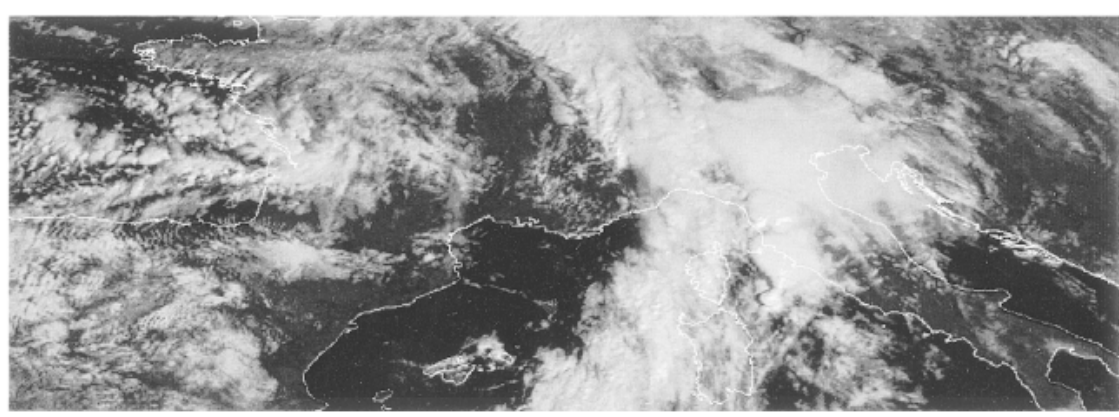

FIG. 4. Still image in the visible channel from Meteosat-6 rapid scan sequence of 20 Sep 1999, 0942 UTC (IOP 2). Very intense convective activity with the development of several large cells over Italy was captured and closely followed by the satellite at 5-min intervals (courtesy of EUMETSAT).

Highly consistent results were obtained by the two techniques. In the case shown in Fig. 7b, the general background stratiform echo was neatly divided into a rain layer (brown colors) and an ice particle layer (pink, blue, and purple colors). The convective echo appearing in red consisted of heavy rain, graupel mixed with rain (green colors), and a few spots where hail is suggested (yellow). This cell was particularly intense, and hail may have actually been present in small amounts. The other algorithm (not shown), which tends to be more conservative, did not indicate hail. This result was rather typical: the convective cells seen in IOP $2 \mathrm{~B}, 3$, and 5 tended to contain a little graupel and only very occasional spots of hail. They showed maximum reflectivity and heavy rain at low levels, indicating the importance of growth by drop coalescence in the lower levels (the "warm rain" process). The relative roles of warm rain and ice processes in the orographic precipitation remains to be evaluated from the full MAP dataset.

Three aircraft in MAP had particle measuring systems on board for documenting the sizes and shapes of precipitation particles: the P-3, Electra, and Merlin. More often than not, air traffic restrictions prevented collection of an optimal microphysical dataset. Nonetheless, several flights by these aircraft collected particle samples at a range of temperatures that should be useful in evaluating the microphysical structure indicated by the S-Pol radar. In situ measurements taken at the mountain station of Macugnaga, Italy $(2800 \mathrm{~m}$ ASL) also support the results of the particle identification algorithms (Barthazy et al. 2000).

While the ground-based radars monitored the orographically modified flow and precipitation continuously and in detail in the LMTA, the MAP research aircraft could explore the precipitation all along the
Alpine barrier. Later in IOP5, on the day following that just described, the precipitation moved eastward, and the cold front crossed northern Italy, the Adriatic, and Slovenia. The P-3 and Electra aircraft conducted an extremely successful coordinated mission documenting the frontal precipitation as it crossed the Adriatic. Figure 8 shows portions of the flight tracks of the two aircraft, while the overall radar echo pattern is supplied by the Italian operational radar at Fossalon di Grado. This figure cannot adequately show the intricate coordination of the aircraft tracks with each other and with the radar echo pattern since the ground-based radar data were for a particular instant of time and the aircraft tracks were for the hour preceding that time. The Fossalon radar data shows that the frontal-banded precipitation extended south over the Mediterranean, yet was also evidently dynamically connected to what was happening over the Alpine slopes to the north. Analysis of the dual-Doppler radar collected on board both aircraft eventually will document the dynamics of this frontal orographic interaction in detail.

\section{b. Incident upper-tropospheric PV anomalies}

The observational strategy for $\mathrm{P} 2$ relied primarily on the Falcon aircraft. In support, the French network of VHF profilers provided continuous measurements of the three wind components and of the tropopause height during the passage of the anomalies. The aircraft missions were usefully guided on the basis of forecasts of the tropopause surface by the ECMWF model. During the SOP the weather was favorable in providing three cases with elongated potential vorticity streamers above central Europe: 27 October, 6-7 November, and 15 November. The Falcon performed four flights collecting in situ data and remotely sensed water vapor and backscatter data with the DIAL lidar aboard the airplane in down-looking mode. Radiosondes launched by the Swiss Army and dropsondes from the Falcon provided additional profile data.

The 6-7 November case is a good example of P2 operations. On 6 November, a trough was elongating meridionally between the North Sea and the Mediterranean Sea. The following day showed a potential vor- 
TABLE 5. Summary of IOP events and operations. The overall interest of each event, combining quality of measurements and physical interest, is given in the last column: *, moderate; **, good; ***, excellent.

\begin{tabular}{|c|c|c|c|c|c|c|}
\hline IOP & Day & Project & Event, location & Operations & Comments & Interest \\
\hline 1 & 15 Sep & $\mathrm{P} 1$ & Convection, Liguria & Electra, radars & Good start! & $*$ \\
\hline \multirow[t]{2}{*}{$2 \mathrm{~A}$} & 17 Sep & $\mathrm{P} 1$ & Squall line, LMTA & Radars, electricity & & $* * *$ \\
\hline & 18 Sep & $\mathrm{P} 1$ & Liguria & Radars, Fokker & Upstream flow sampling & $* *$ \\
\hline \multirow[t]{14}{*}{$2 \mathrm{~B}$} & 19 Sep & P6 & Waves, Jungfrau & Electra & Weak case, one track over & * \\
\hline & & & & & Rhine Valley & \\
\hline & & P5 & Foehn, Rhine valley & Merlin, soundings in RV, CVB & Strong case & $* * *$ \\
\hline & 20 Sep & $\mathrm{P} 1$ & Heavy rainfall, LMTA & Radars, Electra & Max precip. $300 \mathrm{~mm}$ & $* * *$ \\
\hline & & $\mathrm{P} 1$ & Heavy rainfall, Veneto & Teolo and Fossalon radars & Max precip. $280 \mathrm{~mm}$ & $* * *$ \\
\hline & & $\mathrm{P} 2$ & PV streamer, France & Wind profilers & & \\
\hline & & $\mathrm{P} 3$ & Flood, LMTA & Dense rain gauge network & $368 \mathrm{~mm}(36 \mathrm{~h})^{-1}$ & $* * *$ \\
\hline & & $\mathrm{P} 4$ & Gap flow, Brenner Pass & Surface stations & & \\
\hline & & P5 & Foehn, Rhine valley & & & \\
\hline & & P6 & Waves, Hohe Tauern & Electra & $\begin{array}{l}\text { Strong } w\left(8 \mathrm{~m} \mathrm{~s}^{-1}\right) \text {, weak } \\
\text { turbulence }\end{array}$ & $* * *$ \\
\hline & 21 Sep & P8 & PBL, Riviera & Dimona & & $*$ \\
\hline & 22 Sep & P8 & PBL, Riviera & Dimona & & $*$ \\
\hline & 22 Sep & $\mathrm{P} 3$ & $\begin{array}{l}\text { Soil moisture, Toce } \\
\text { valley }\end{array}$ & Microwave rad. on helicopter & & \\
\hline & 23 Sep & P3 & $\begin{array}{l}\text { Soil moisture, Toce } \\
\text { valley }\end{array}$ & Microwave rad. on helicopter & & \\
\hline \multirow[t]{6}{*}{3} & $24 \mathrm{Sep}$ & $\mathrm{P} 1$ & $\begin{array}{l}\text { Surface fluxes, Po } \\
\text { valley }\end{array}$ & Merlin, Fokker, radars & Radars in clear-air mode & $* *$ \\
\hline & $25 \mathrm{Sep}$ & $\mathrm{P} 1$ & Heavy rainfall, LMTA & Electra, Fokker, radars & & $* * *$ \\
\hline & $26 \mathrm{Sep}$ & $\mathrm{P} 1$ & Heavy rainfall, LMTA & Fokker, radars & $\begin{array}{l}\text { Max precip. over } 400 \mathrm{~mm} \\
\text { for the two days }\end{array}$ & \\
\hline & & P3 & Flood, LMTA & & & \\
\hline & $28 \mathrm{Sep}$ & P8 & PBL, Riviera & Dimona & & $* * *$ \\
\hline & 29 Sep & P8 & PBL, Riviera & Dimona, DOW radar & & $* * *$ \\
\hline \multirow[t]{4}{*}{4} & $30 \mathrm{Sep}$ & $\mathrm{P} 1$ & Front, LMTA & $\begin{array}{l}\text { Radars, Electra, P-3, Fokker } \\
\text { CVB, electricity }\end{array}$ & & $* *$ \\
\hline & & $\mathrm{P} 2$ & PV streamer, France & Wind profilers & & \\
\hline & $1 \mathrm{Oct}$ & $\mathrm{P} 7$ & Mistral, southern Alps & Electra, P-3 & $\begin{array}{l}\text { Clear primary banner, } \\
\text { indication of secondary } \\
\text { banners }\end{array}$ & $* * *$ \\
\hline & & P8 & PBL, Riviera & Dimona & & $* * *$ \\
\hline
\end{tabular}


TABle 5. Continued.

\begin{tabular}{|c|c|c|c|c|c|c|}
\hline IOP & Day & Project & Event, location & Operations & Comments & Interest \\
\hline \multirow[t]{5}{*}{5} & 2 Oct & $\mathrm{P} 4$ & Gap flow, Brenner & Electra, P-3, Lidar & $\begin{array}{l}\text { Data from P-3 } \\
\text { irrecoverable? }\end{array}$ & $* *$ \\
\hline & & P5 & Foehn, Rhine valley & $\begin{array}{l}\text { Merlin, Dimona, soundings, } \\
\text { CVB, lidar }\end{array}$ & Good shallow foehn & $* *$ \\
\hline & 3 Oct & $\mathrm{P} 1$ & Active front, LMTA & Radars, electricity & $\begin{array}{l}\text { Max precip. } 280 \mathrm{~mm} \text {, } \\
\text { semicircular cells }\end{array}$ & $* *$ \\
\hline & 4 Oct & $\mathrm{P} 1$ & Convection, Slovenia & Electra, P-3 & $\begin{array}{l}\text { Fossalon di Grado } \\
\text { available }\end{array}$ & $* * *$ \\
\hline & & $\mathrm{P} 2$ & Low tropopause, LMTA & Wind profilers & & \\
\hline 6 & 13 Oct & $\mathrm{P} 1$ & Stratiform rain, LMTA & Radars, Electra, P-3 & Some microphysics useful & $*$ \\
\hline \multirow[t]{2}{*}{7} & 18 Oct & $\mathrm{P} 1$ & Stratiform rain, Liguria & Radars, Electra, P-3 & & $*$ \\
\hline & & & LMTA & Merlin & Icing study & $* * *$ \\
\hline \multirow[t]{9}{*}{8} & 19 Oct & P5 & Rhine valley & Fokker, CVB, lidar & $\begin{array}{l}\text { Prefoehn flight for } \\
\text { STAARTE }\end{array}$ & \\
\hline & 20 Oct & $\mathrm{P} 1$ & Precip, LMTA & Radars & & $*$ \\
\hline & & $\mathrm{P} 4$ & Gap flow, Brenner & Electra, P-3, lidar & & $* *$ \\
\hline & & P5 & Foehn, Rhine valley & Merlin, CVB, lidar & $\begin{array}{l}\text { Strong foehn and } \\
\text { turbulence }\end{array}$ & $* * *$ \\
\hline & $21 \mathrm{Oct}$ & $\mathrm{P} 1$ & Stratiform rain, LMTA & P-3, Fokker, radars, electricity & $\begin{array}{l}\text { Excellent microphysics } \\
\text { measurements (missed } \\
\text { approach) }\end{array}$ & $* *$ \\
\hline & & & $\begin{array}{l}\text { Heavy rain, Veneto } \\
\text { region }\end{array}$ & Teolo and Fossalon radars & $100-150 \mathrm{~mm}$ & \\
\hline & & $\mathrm{P} 4$ & Gap flow, Brenner Pass & Doppler lidar, surface stations & $\begin{array}{l}\text { Strongest case, but no } \\
\text { aircraft }\end{array}$ & $* *$ \\
\hline & & P5 & Foehn, Rhine valley & CVB, lidar & & \\
\hline & & $\mathrm{P} 6 / 7$ & $\begin{array}{l}\text { Waves and PV banners, } \\
\text { Ötztaler Alps }\end{array}$ & Electra & & $* * *$ \\
\hline \multirow[t]{3}{*}{9} & 23 Oct & $\mathrm{P} 1$ & $\begin{array}{l}\text { Heavy rain, Liguria } \\
\text { and Po valley }\end{array}$ & Electra, P-3, radars & $\begin{array}{l}\text { Stratiform precip. over } \\
\text { the slopes }\end{array}$ & $* *$ \\
\hline & & $\mathrm{P} 2$ & PV streamer, France & Wind profilers & & \\
\hline & & P5 & Rhine valley & Merlin, Sfc, CVB, lidar & & \\
\hline \multirow[t]{7}{*}{10} & 24 Oct & $\mathrm{P} 1$ & Rain, LMTA & P-3, Fokker, CVB & & $*$ \\
\hline & & & LMTA & Merlin & Icing study & $*$ \\
\hline & & $\mathrm{P} 2$ & PV streamer & Profilers & & \\
\hline & & $\mathrm{P} 4$ & Gap flow, Brenner Pass & Electra & No SABL (clouds) & $*$ \\
\hline & & P5 & Foehn, Rhine valley & & & \\
\hline & 25 Oct & & LMTA & Merlin, radars & Icing study & $* *$ \\
\hline & & P6 & Waves, Grossglockner & Falcon & Good data from DIAL & $* * *$ \\
\hline
\end{tabular}


TABle 5. Continued.

\begin{tabular}{|c|c|c|c|c|c|c|}
\hline IOP & Day & Project & Event, location & Operations & Comments & Interest \\
\hline \multirow[t]{3}{*}{11} & 27 Oct & $\mathrm{P} 1$ & $\begin{array}{l}\text { Surface fluxes, Po } \\
\text { valley }\end{array}$ & Merlin, Fokker, radars & Radars in clear-air mode & $* * *$ \\
\hline & & $\mathrm{P} 2$ & $\begin{array}{l}\text { PV streamer, above } \\
\text { Alps }\end{array}$ & Falcon, profilers & & $* *$ \\
\hline & $28 \mathrm{Oct}$ & $\mathrm{P} 3$ & $\begin{array}{l}\text { Soil moisture, Toce } \\
\text { valley }\end{array}$ & Microwave rad. on helicopter & & \\
\hline \multirow[t]{4}{*}{12} & 29 Oct & P3 & $\begin{array}{l}\text { Soil moisture, Toce } \\
\text { valley }\end{array}$ & Microwave rad. on helicopter & & \\
\hline & $30 \mathrm{Oct}$ & $\mathrm{P} 1$ & Weak rain, French Alps & Electra, radars, CVB & $\begin{array}{l}\text { Some microphysics } \\
\text { over LMTA }\end{array}$ & $*$ \\
\hline & & $\mathrm{P} 4$ & Brenner, gap flow & Electra, P-3, Fokker, lidar & $\begin{array}{l}\text { Hydraulic jump well } \\
\text { documented, excellent } \\
\text { data from LEANDRE } 2\end{array}$ & $* * *$ \\
\hline & & P5 & Foehn, Rhine valley & Sfc & & \\
\hline \multirow[t]{4}{*}{13} & $1 \mathrm{Nov}$ & $\mathrm{P} 4$ & Brenner, gap flow & Electra & Good SABL data & $* *$ \\
\hline & & P5 & Foehn, Rhine valley & Sfc & & \\
\hline & $2 \mathrm{Nov}$ & P5 & Foehn, Rhine valley & Merlin, CVB, lidar & & $*$ \\
\hline & & P6 & 3D waves, Mont Blanc & C130, Electra, Fokker, Falcon & Moderate amplitude & $* * *$ \\
\hline \multirow[t]{5}{*}{14} & $3 \mathrm{Nov}$ & $\mathrm{P} 1$ & Convection, Liguria & Electra, P-3, Fokker, radars & $\begin{array}{l}\text { Strong case, excellent } \\
\text { data }\end{array}$ & $* * *$ \\
\hline & & & LMTA & Merlin & Icing study & $* *$ \\
\hline & & $\mathrm{P} 2$ & PV streamer, France & Wind profilers & & \\
\hline & 4 Nov & $\mathrm{P} 1$ & Stratiform rain, LMTA & Radars, Electra, P-3, Fokker & Fokker over Adriatic Sea & $* * *$ \\
\hline & & & LMTA & Merlin, S-Pol & Icing study & $* * *$ \\
\hline \multirow[t]{11}{*}{15} & $5 \mathrm{Nov}$ & P5 & Foehn, Rhine valley & Fokker, Merlin, CVB & & $* * *$ \\
\hline & $6 \mathrm{Nov}$ & $\mathrm{P} 1$ & Heavy rain, LMTA & $\begin{array}{l}\text { Radars, Electra (short ferry } \\
\text { only) }\end{array}$ & $\begin{array}{l}\text { Strong winds and local } \\
\text { floods }\end{array}$ & $* *$ \\
\hline & & $\mathrm{P} 2$ & PV streamer, NE France & Falcon, wind profilers & & $* * *$ \\
\hline & & P4 & Gap flow, Brenner & $\mathrm{P}-3$ & $\begin{array}{l}\text { Good evidence of the } \\
\text { Wipptal jet }\end{array}$ & $* *$ \\
\hline & & P6 & Waves, Hohe Tauern & Electra, C130, Falcon & Weak waves & $*$ \\
\hline & & & Waves, Wallis Alps & $\mathrm{C} 130$ & & \\
\hline & & $\mathrm{P} 7$ & Mistral & Electra, P-3, Merlin, Fokker & Strong mistral & $* * *$ \\
\hline & $7 \mathrm{Nov}$ & $\mathrm{P} 1$ & $\begin{array}{l}\text { Heavy rain, Veneto and } \\
\text { Northern Appennines }\end{array}$ & $\begin{array}{l}\text { Teolo, Fossalon and SP } \\
\text { Capofiume radars }\end{array}$ & $\begin{array}{l}\text { Over } 100 \mathrm{~mm} \text { in } 12-\mathrm{h} \text {, } \\
\text { local floods }\end{array}$ & $*$ \\
\hline & & $\mathrm{P} 2$ & $\begin{array}{l}\text { PV streamer, above } \\
\text { Alps }\end{array}$ & Falcon, profilers & & $* * *$ \\
\hline & & P6 & Waves, Monte Rosa & Falcon & & \\
\hline & & $\mathrm{P} 7$ & Bora, Adriatic & Electra, P-3 & $\begin{array}{l}\text { Strong case, PV banners, } \\
\text { Hydraulic jump }\end{array}$ & $* * *$ \\
\hline
\end{tabular}


TABLE 5. Continued.

\begin{tabular}{|c|c|c|c|c|c|c|}
\hline IOP & Day & Project & Event, location & Operations & Comments & Interest \\
\hline & \multirow[t]{2}{*}{$8 \mathrm{Nov}$} & P6 & Waves, Monte Rosa & Electra, C130, Falcon & $\begin{array}{l}\text { Possibly breaking at } \\
\text { Falcon level }\end{array}$ & $* *$ \\
\hline & & $\mathrm{P} 7$ & PV banners, Po valley & $\begin{array}{l}\text { P-3, Fokker, Merlin, Ronsard, } \\
\text { CVB }\end{array}$ & $\begin{array}{l}\text { Strong banners from } \\
\text { Gotthard and Brenner, } \\
\text { Ronsard in clear-air mode }\end{array}$ & $* * *$ \\
\hline & $9 \mathrm{Nov}$ & $\mathrm{P} 7$ & PV banners, Po valley & Fokker, Merlin & $\begin{array}{l}\text { Much weaker than previous } \\
\text { day }\end{array}$ & s * \\
\hline \multirow[t]{7}{*}{16} & $11 \mathrm{Nov}$ & $\mathrm{P} 1$ & Stratiform rain, LMTA & Ronsard, Electra & $\begin{array}{l}\text { One intercomparison leg } \\
\text { with Merlin }\end{array}$ & $*$ \\
\hline & & & $\begin{array}{l}\text { Surface fluxes, Po } \\
\text { valley }\end{array}$ & Merlin & & \\
\hline & & P5 & Foehn, Rhine valley & & & \\
\hline & $12 \mathrm{Nov}$ & $\mathrm{P} 4$ & Gap flow, Brenner & Electra, P-3 & & $*$ \\
\hline & & P5 & Foehn, Rhine valley & & & \\
\hline & $13 \mathrm{Nov}$ & P5 & Foehn, Rhine valley & & & \\
\hline & & P6 & Waves, French Alps & Falcon, C130, Electra & $\begin{array}{l}\text { Possibly breaking below } \\
\text { a critical level }\end{array}$ & $*$ \\
\hline 17 & $15 \mathrm{Nov}$ & $\mathrm{P} 2$ & $\begin{array}{l}\text { PV streamer, above } \\
\text { Alps }\end{array}$ & Falcon & & $* * *$ \\
\hline
\end{tabular}

ticity streamer strongly narrowing between Denmark and northern Italy, forming a cutoff low at its south-

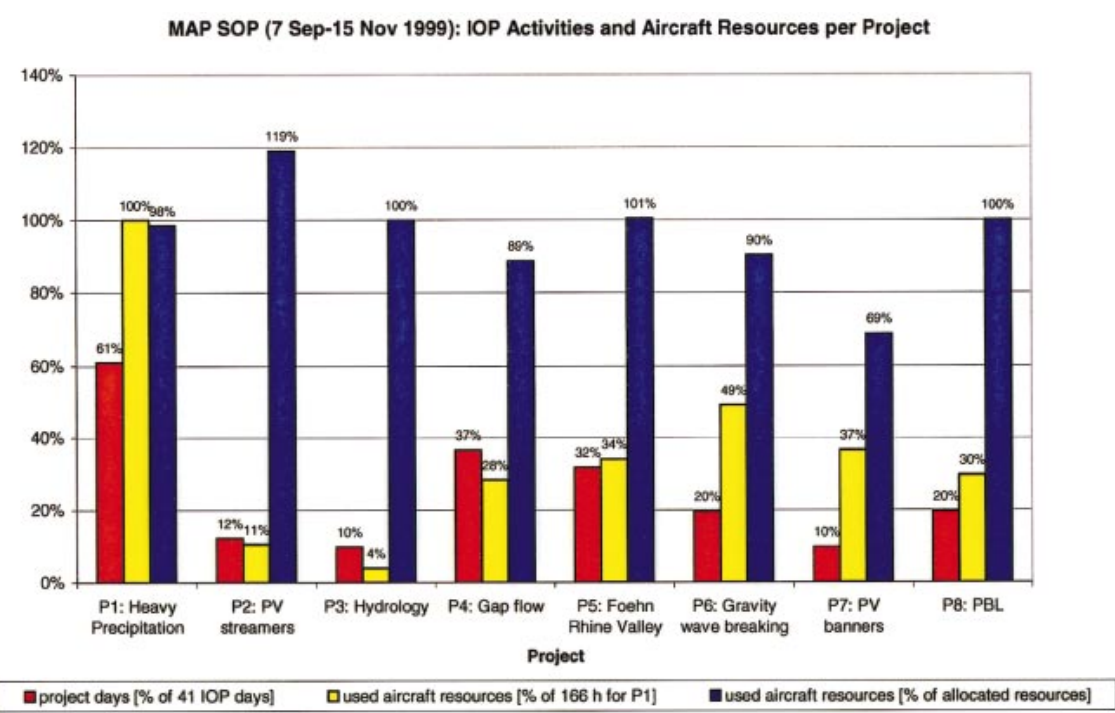

FIG. 5. Summary of resource usage by projects during the SOP. Yellow bars show the number of flight hours used by each project, the reference being the largest one (P1) (166 h). Blue bars indicate the proportion of the initially apportioned resources for each project. The red bars indicate the number of days when a major facility has been activated for each project. ern end above Italy and above the islands of Corsica and Sardinia. The ECMWF analysis depicted significant tropopause folds at the western and eastern edges of the streamer. These folds transported stratospheric air down to a height of less than $6 \mathrm{~km}$. On 6 November, the Falcon performed the following flight pattern at $12 \mathrm{~km}$. It flew from Munich, Germany, to Brest then to Bordeaux, France, and Venice, Italy, and finally back to Munich. This flight pattern was designed to obtain cross-streamer curtains of water vapor data at two different locations. The DIAL data obtained on the southern section along $45^{\circ} \mathrm{N}$ from Bordeaux to Venice are shown in Fig. 9. The determination of the low humidities (below 300 ppmv) in the lower stratosphere and upper 

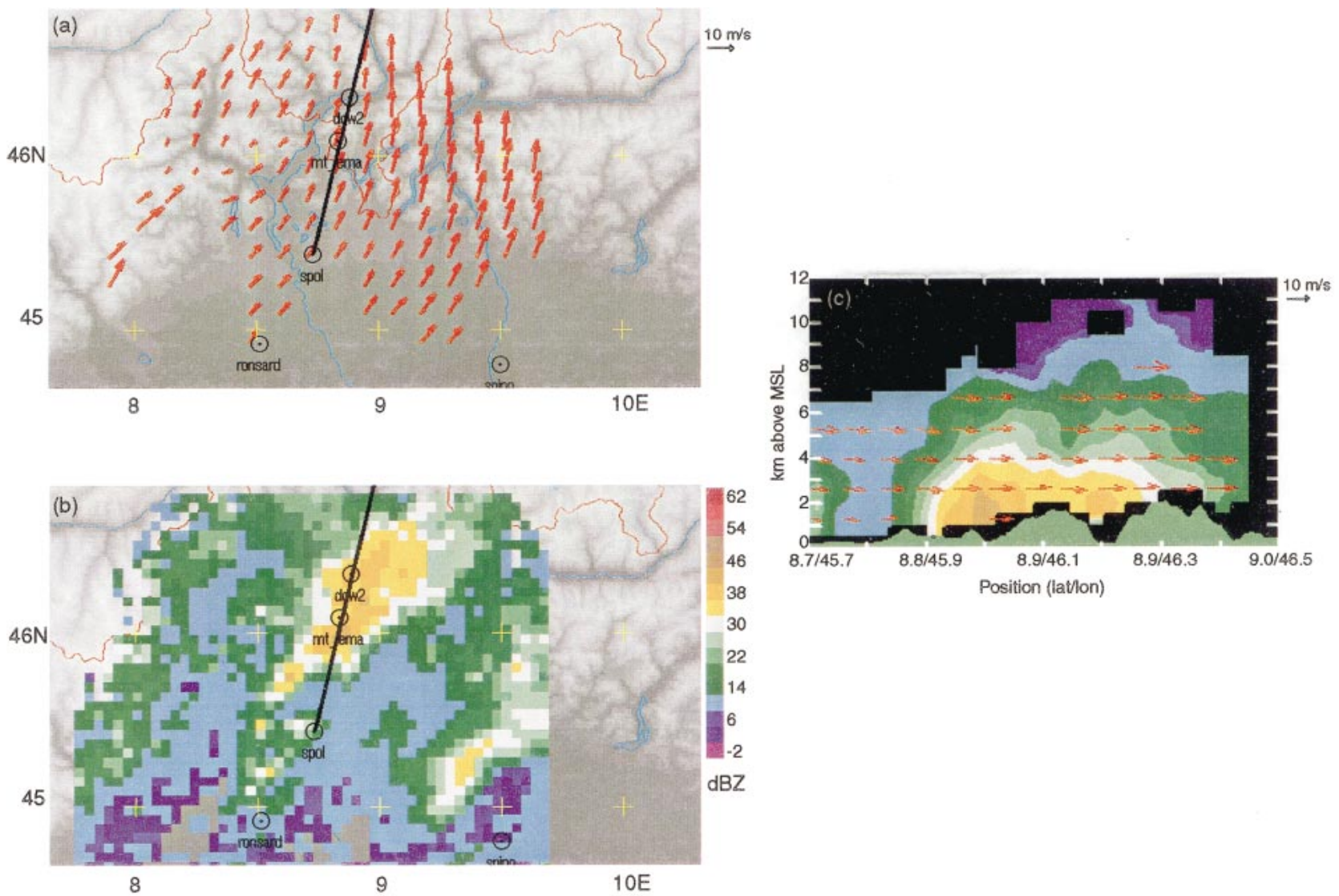

FIG. 6. (a) Dual-Doppler winds for the 2.5-km level computed from the Monte-Lema and Ronsard radars at 1814 UTC 3 Oct 1999. Topography is in gray shades with higher elevations lighter. A radial taken north-northeastward from the S-Pol radar is the black line. (b) Composite radar reflectivity corresponding to the winds in (a). (c) Vertical cross section of S-Pol radar reflectivity along the radial line shown in (a) and (b) with dual-Doppler zonal wind component superimposed.

troposphere follows the technique described in Ehret et al. (1999). The high horizontal resolution relies on the $100-\mathrm{Hz}$ repetition frequency of the laser pulses, a so far unique application of an airborne DIAL system. On the following day similar measurements were obtained along five meridionally stacked zonal sections between the western and eastern borders of Germany. The data collected during this case will be very useful for the description of the mesoscale features of the streamer and its development and modification into a narrow elongated structure. The data of the last case (15 November) show a vertical cross section cutting through the entire streamer located above the Alps. During both periods, the streamers were dynamically active and the measurement systems worked perfectly.

\section{c. Hydrological measurements and flood forecasting}

Project P3 focused on the Ticino and Toce River catchments, both tributaries of the Lago Maggiore. A special network of 14 rain gauges (13 of them property of the University of Waterloo) was deployed by the University of Brescia in two lateral valleys of the Toce valley (Val Anzasca and Val Vigezzo). In addition, several teams organized soil moisture and micrometeorological monitoring campaigns in the Toce area. Among other instruments, a time-domain reflectrometry (TDR) with 14 probes was deployed by the University of Modena. Finally, a passive radiometer operating in three different microwave bands $(\mathrm{L}$, $\mathrm{C}, \mathrm{X}$, the last two with horizontal and vertical polarization) was used on board a helicopter by the CNRIROE Institute. This experiment was intended to evaluate the potential of short-distance radiometric soil moisture measurements over some selected sites, where ground and laboratory data were available for verification and antenna calibration. Two missions were performed, one after the heavy rain event of 2021 September (IOP 2), the other during the soil drying stage after the rainfall event of 21-25 October 

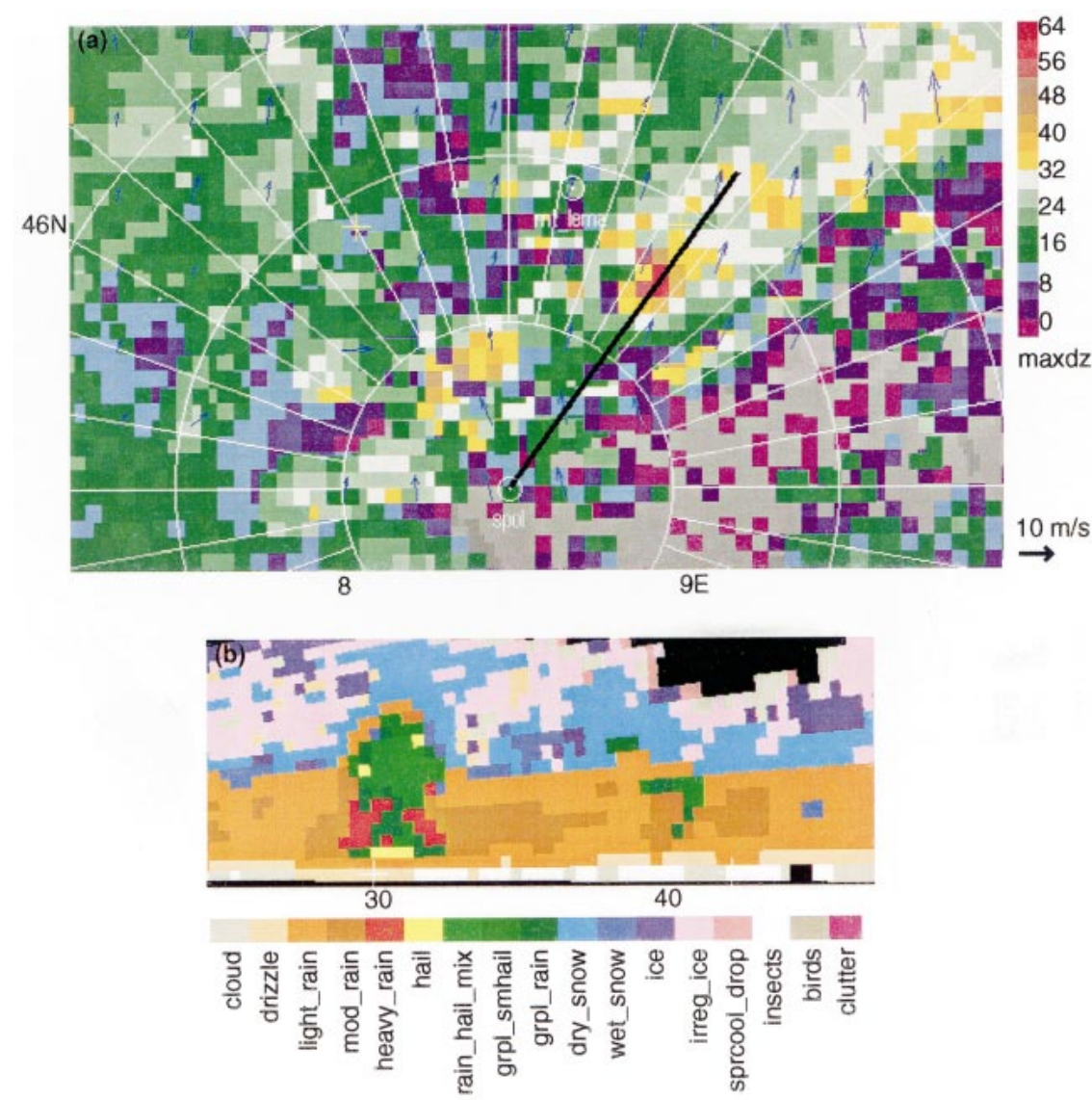

FIG. 7. (a) Radar reflectivity (composite of S-Pol, Ronsard, and Monte-Lema radars) and dual-Doppler wind (computed from Ronsard and Monte-Lema) for the 3-km level at 1541 UTC 3 Oct 1999. Range marks are at 20-km intervals from the S-Pol radar. A radial taken northeastward from the S-Pol is the black line. (b) Particle types computed by NCAR algorithm from polarimetric variables measured by $\mathrm{S}-\mathrm{Pol}$ radar along this radial. versities of Brescia, Genova, and ISAO-CNR) used the output of the BOLAM meteorological mode (run during MAP with a $6.5-\mathrm{km}$ grid, starting from ECMWF analyses) for driving the Distributed Hydrological Model for the SOP (DIMOSOP) model (25-m resolution), applied to the Toce watershed. The latter is a small to midsize ba$\sin \left(1532 \mathrm{~km}^{2}\right)$ characterized by very steep orography. It was probably the first time that such coupled high-resolution meteohydrological deterministic models were used in quasi-real time.

The input for the hydrological models were the hourly precipitation and surface parameters predicted by the meteorological models. They benefited also from the special field observations acquired in the Toce and Riviera valleys. Moreover, the forecasting experiment used the measurements of water levels in some hydroelectric reservoirs, and the snow height and soil water content available at some representative places for the definition of the initial condi-
(IOPs 8, 9, 10). A first evaluation of the data indicates that meaningful results could be obtained over bare soils, or soils covered by uniform vegetation (grass or smooth crops). However, L-band measurements were hindered by external electromagnetic interferences. In situ soil measurements, complemented by boundary layer atmospheric measurements of Project P8, were also taken in the Riviera valley and other lateral valleys by ETH (Institute for Climate Research).

The numerical part of P3 consisted of two different attempts to produce real-time runoff and flood forecasts, using coupled meteorological and hydrological models. A Canadian team (University of Waterloo and AES) coupled the very fine resolution (3-km grid) MC2 model (see section 2d) to the WATFLOOD distributed hydrological model (2-km grid), in order to produce flood forecasts for both the Ticino-Toce watershed and the Ammer watershed in the Bavarian Alps. In parallel, an Italian team (Uni- tions of the watershed. The DIMOSOP model included in a simplified manner a treatment of the formation and propagation of the surface runoff along the mountain slopes, of the subsurface contribution and of the flow dynamics within the river channels. The simulation of the behavior of soils required both in situ and laboratory measurements. The riverbed characteristics had been surveyed prior to the experiment along several cross sections.

The flood forecasts, provided at nine hydrometric sections and 10 hydroelectric basins, were prepared daily with a lead time of 24-30 h, based on the 36-h forecast by the mesoscale meteorological models. Figure 10 shows an example of such a forecast, made for the event of most intense precipitation (IOP 2). A 5 -yr return period flood was observed in this case. The figure indicates that the forecast overestimated the peak runoff. This is probably due to an overestimation of the rainfall peak intensity in the meteorological 


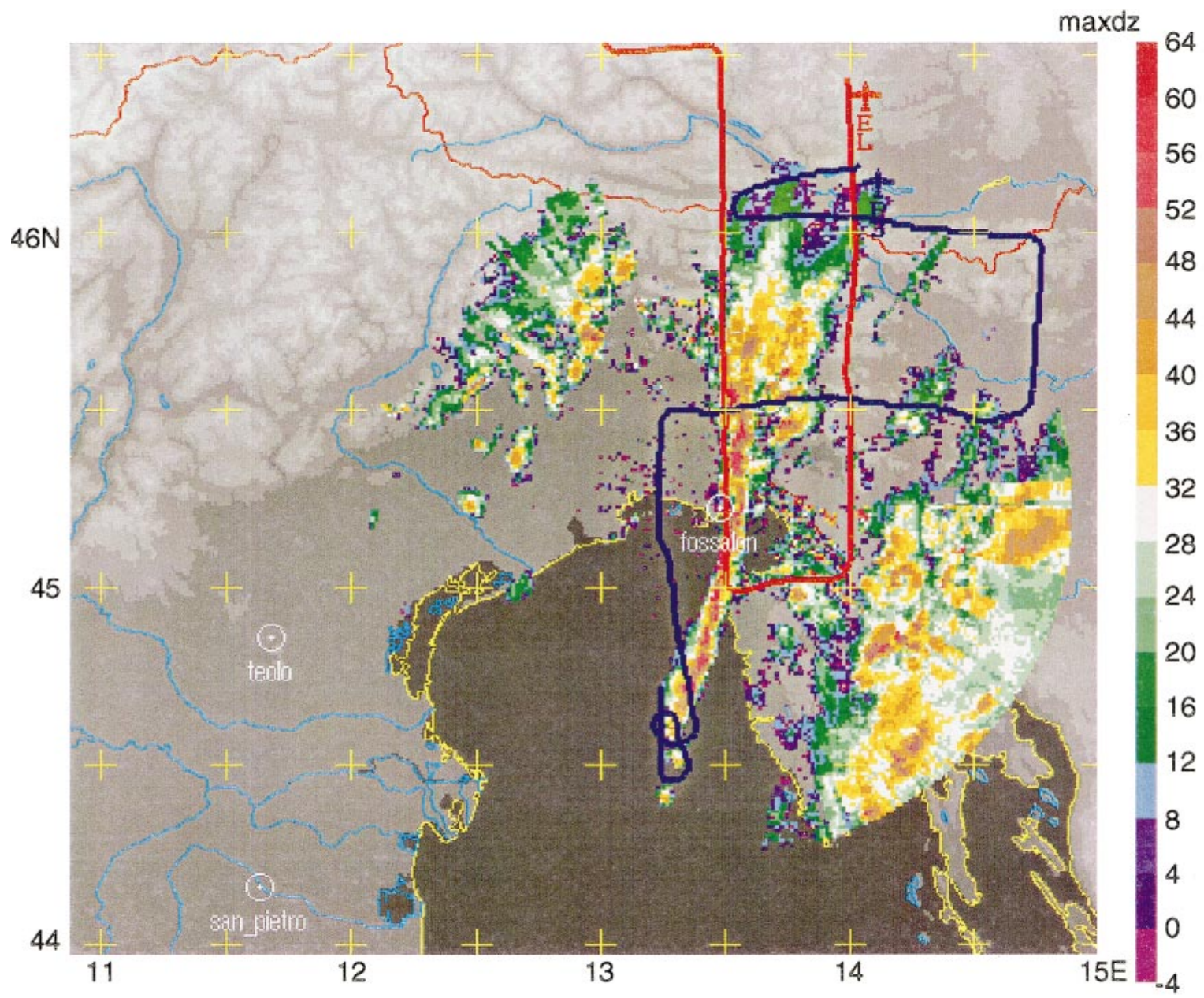

FIG. 8. Radar reflectivity (dBZ color scale) observed by the Italian operational radar at Fossalon di Grado at 0800 UTC 4 Oct 1999. One-hour flight tracks of Electra (red) and P-3 (blue) aircraft ending at 0800 UTC.

model, as shown in the upper part. However, the timing of the peak and of the rising limb of the flood were properly captured and the predicted rainfall and runoff volumes were close to the observed ones. In general, a preliminary evaluation of both flood forecasting experiments indicates useful and encouraging results. The quality of the flood forecasts mainly depends on the quality of the precipitation forecasts by meteorological models, especially the temporal and spatial localization of the intense events. No significant false alarms were issued in the Ticino-Toce watershed, although the number of flood events was very small during the SOP. The hydrological model component turned out to be sensitive also to the type of precipitation (rain or snow) as a function of height and to the melting of the snow cover.

In parallel to the above-mentioned coupled modeling efforts, a real-time precipitation forecast was issued by the University of Grenoble for different areas in the western Alps including the Ticino-Toce watershed, based on the technique of "meteorological analog": a series of meteorological situations analogous to the current one was searched every day, and the precipitation forecast was based on the histograms of rain observed on each watershed during the analogous situations. The comparison of the performances of this method and conventional numerical forecasts is currently under progress.

\section{d. Dynamics of gap flow in the Wipp valley}

Project $\mathrm{P} 4$ focused on the flow through the Brenner Pass into the Wipptal, a south-north-oriented tributary to the Inn valley close to Innsbruck. Groundbased measurements installed and operated primarily by the University of Innsbruck included several profilers, sodars, and special radio-sounding systems, a network of microbarographs, and the NOAA scanning Doppler lidar at Gedeir. Flight missions by the 


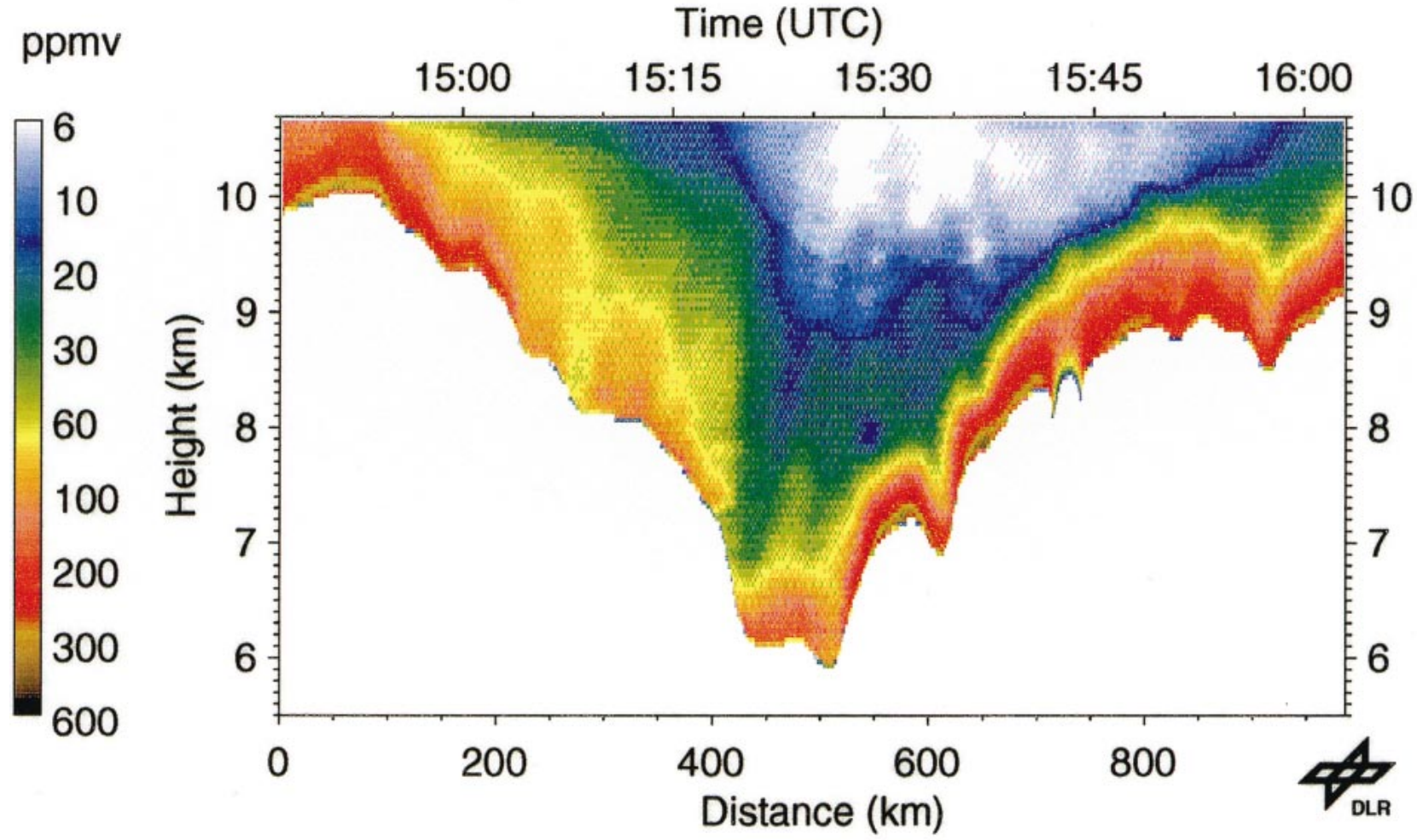

FIG. 9. Section of low water vapor concentration $(<300 \mathrm{ppmv})$ across an active potential vorticity streamer connected with a tropopause fold; data obtained on 6 Nov with an airborne H20-DIAL looking down from $11 \mathrm{~km}$. The flight segment is along $45^{\circ} \mathrm{N}$ from Bordeaux (left) to Venice (right) with the western Alps in the middle (courtesy of G. Ehret).

Electra and P-3 aircraft, the Fokker, and the Dornier 228, acquired both in situ measurements of the flow and vertical cross sections by downward-looking lidars and dropsondes. The SOP was also the occasion to undertake the first scientific flights of the new WIND lidar on board the Falcon. Developed as a joint French-German project, WIND is an airborne wind Doppler lidar that implements a down-looking conical scan capability. It can map the radial wind velocity with high horizontal (vertical) resolution, and reconstruct the mesoscale wind field outside cloudy areas with a $10-\mathrm{km}(250 \mathrm{~m})$ resolution.

The large degree of cloudiness associated with foehn events came as a surprise, and prevented lidar operations on several occasions. This could be compensated for by operating the Eldora radar on some occasions when the droplet sizes were sufficient. However, interesting lidar measurements were obtained during several flight missions, and were occasionally reinforced by the presence of Saharan dust. The dropsonde operations required specific training, because the Wipptal is a narrow valley. In a couple of cases, an almost simultaneous series of three or four sondes along the valley were obtained. Low-level flights of the P-3 in the Wipptal were not planned in advance because they were thought to be technically too difficult. However, they were made possible by the intense efforts of the mission scientists, the P-3 crew and Austrocontrol ATC.

Examples of flows observed in $\mathrm{P} 4$ are provided in Figs. 11 and 12. Figure 11 shows a vertical cross section along the Wipp valley observed by the downwardlooking LEANDRE 2 lidar on board the Fokker, during IOP 12. The Brenner Pass is to the left and Innsbruck is at $47.25^{\circ} \mathrm{N}$. The underlying topography is outlined by the transition from dark blue to cream color. The layer appearing in cream above the topography is the lidar surface echo. The region appearing in yellow/green represents the "aerosol mixed layer" while the orange is the free troposphere. The gap flow is observed between $47.1^{\circ}$ and $47.25^{\circ} \mathrm{N}$. It is evidenced by the thinning aerosol mixed layer in the region where the flow becomes supercritical. After $47.25^{\circ} \mathrm{N}$, a hydraulic jump is suspected, as evidenced by the sudden rise of the mixed-layer top. Figure 12 shows cross sections of the radial velocity measured by the NOAA scanning Doppler lidar at Gedeir on the same day. It reveals the low-level jet resulting from the hydraulic 


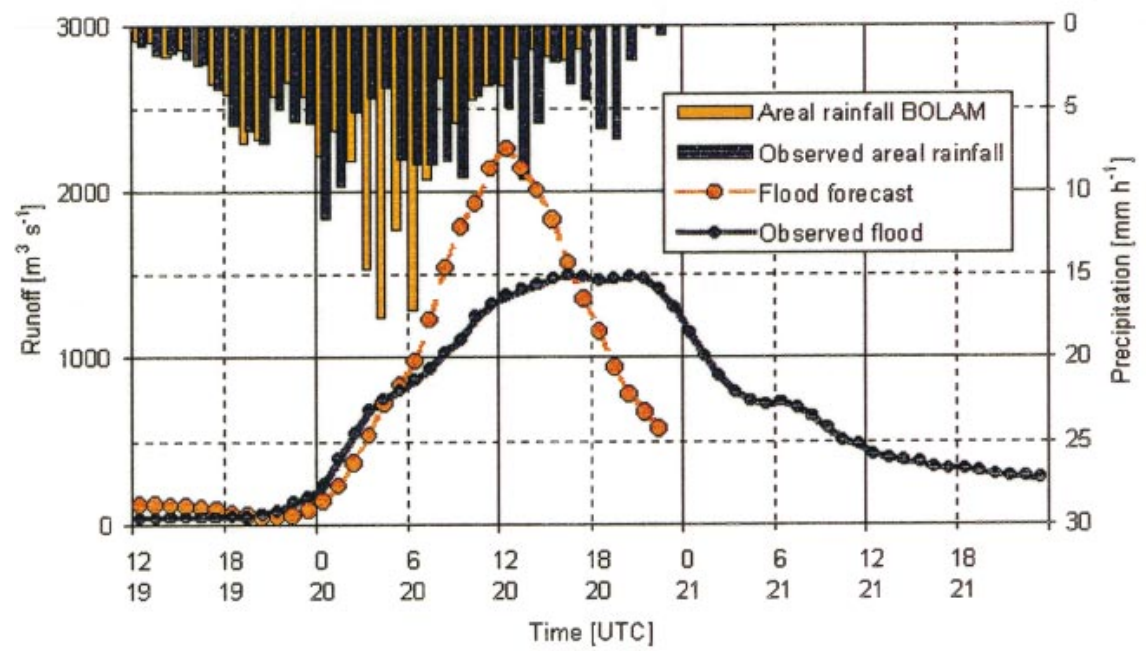

FIG. 10. Observed and forecasted flow of the Toce River at Candoglia, for 19 and 20 Sep 1999. The forecast is from the DIMOSOP model forced by the BOLAM atmospheric model for period 19 Sep 1200 UTC to 21 Sep 0000 UTC. The observed precipitation is estimated from 18 automatic rain gauges, and totals to $164 \mathrm{~mm}$. The amount predicted by BOLAM is $179 \mathrm{~mm}$ (courtesy of R. Ranzi).

behavior of the flow. We note the wavy wind structure in the upper panels (best seen near 2-km altitude) and the near-surface jet larger than $12 \mathrm{~m} \mathrm{~s}^{-1}$ in the lower panel.

\section{e. Nonstationary aspects of Foehn in the Rhine valley}

The instrumentation for P5 was installed in such a way to give, for the first time, a mesogamma-scale description of the mass and wind fields in the Rhine valley and its main tributaries. Seven special radio-sounding stations, installed in a dense triangular pattern along the valley, launched 3-hourly soundings during the IOPs. Numerous automatic and micrometeorological stations were also operated, and several remote sensing instruments (wind profiler, RASS, lidars and sodars) gave quasicontinuous information on the vertical profile of the atmosphere during more than two months. The Transportable Wind Lidar (TWL) Scanning Doppler lidar allowed a three-dimensional exploration of the wind field within a part of the valley. Tethered balloons, cable cars, and even automobiles were instrumented. At one specific site, two scintil- lometers were installed to monitor the flow along the valley at $500 \mathrm{~m}$ above the ground. A series of video and still cameras documented the behavior of the hazy or foggy cold air pool beneath the clear foehn air. Flight missions of the Merlin aircraft and of the Dimona light research aircraft were conducted at low altitudes during major foehn events. Finally, constant volume balloons launched from the Italian side and a wind profiler at the Julier Pass (Vogt et al. 2000) were used to construct the flow trajectory from the upstream side of the Alps toward the Rhine valley.

Close to Bad Ragaz, the Rhine valley makes a significant turn to the north toward Lake Constance, while another opening is oriented to the northwest toward the Walensee. The main flow is usually heading north or northwest. Observations suggest that the direction of the main flow is determined by the upstream profile of static stability. The TWL scanning lidar (Drobinski et al. 2000) was installed in Vilters, Switzerland, close to the bifurcation point and its measurements will allow an investigation of the dynamics of the flow in this particular area. Figure 13 shows the radial velocity

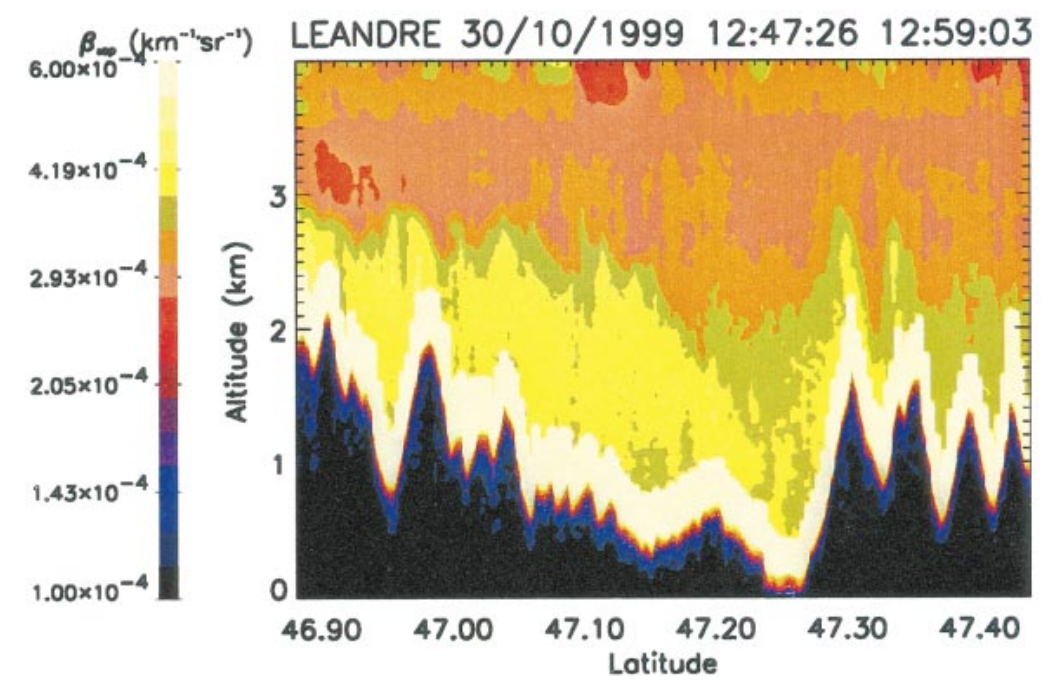

FIG. 11. Cross section along the Wipptal obtained on 30 Oct 1999 by the LEANDRE 2 downward-looking lidar, on board the Fokker 27 ARAT (courtesy of C. Flamant). 


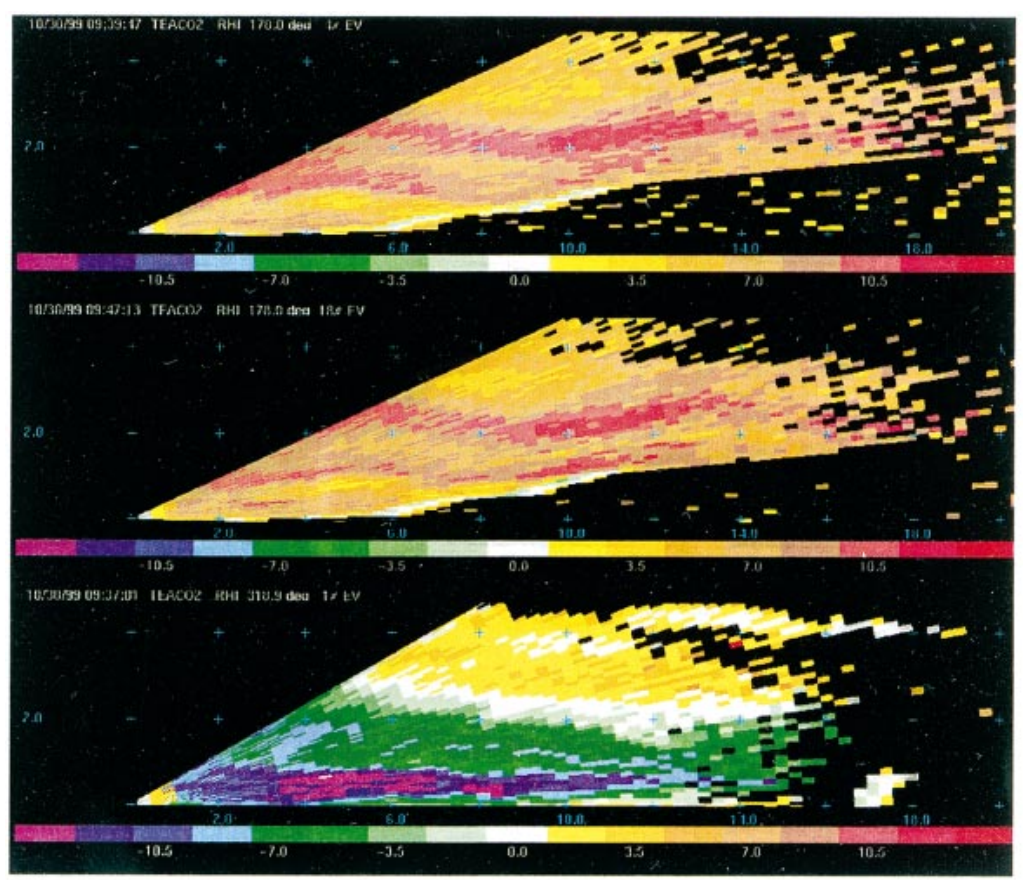

FIG. 12. Gap flow velocity measurements over Brenner Pass by the NOAA scanning Doppler lidar on the morning of 30 Oct 1999. (top two panels) Vertical cross sections of radial velocity, $8 \mathrm{~min}$ apart, pointing to the south along the Wipp valley, showing flow coming over the Brenner Pass. (bottom panel) Same as top panels, except looking downstream toward Innsbruck. Color bars of the velocity in $\mathrm{m} \mathrm{s}^{-1}$ (white numbers) with positive values (red, brown, yellow) indicating flow toward the lidar. Blue numbers indicate distance from the lidar in $\mathrm{km}$ (courtesy of R. Banta and L. Darby).

field on 29 October (at about 1800 UTC) derived from the raster scan procedure.

The TWL is located at the center of the figure. The negative radial velocities correspond to a flow blowing toward the TWL, while positive radial velocities correspond to a flow blowing away from the TWL. The white area of the grid corresponds to the topography or unreliable radial velocity estimates (low signal-to-noise ratio). In the present case, the channeled flow is blowing from Walensee toward the upper Rhine valley. In the lower Rhine valley leading to Lake Constance, there is no evidence of a privileged flow direction.

A question of special importance for the air quality in the densely populated region close to Lake Constance is the behavior of the cold air pool during foehn. In the cold season the area sometimes suffers from air pollution due to a long duration of stagnant boundary layer. Foehn brings a sudden relief of pollution and is therefore welcomed by the population. The present forecasts of local foehn are poor and it is hoped that the MAP scientific investigations will improve it. Observations showed that the ability of the foehn flow to erode the cold pools is strongly influenced by the valley orientation, meanders, and bottlenecks. Side valleys also play a major role. Aircraft observations at low levels have shown that the boundary between the cold and warm air is not forming a retarding wedge, but is rather irregular with a strong temporal and spatial variability. This may explain why the wind damage at the ground is so variable in space. The behavior of the cold air pool close to Lake Constance was observed by RASS, sodar, tethered balloons, and an instrumented cable car at Pfaender Mountain, carrying thermodynamic and ozone sensors. Several foehn events showed a wavy but rather irregular evolution of the boundary between the two air masses. Figure 14 shows the time evolution of the ozone concentration profile on 22 October. The increase of ozone during the afternoon is due to the Foehn layer eroding the surface cold air pool and penetrating down to the ground. Indeed, $\mathrm{NO}_{x}$ and other pollutants destroy the ozone under these specific conditions, and the cleaning effect of the Foehn results in an increase of ozone. The net effect is however an effective relief of pollution in the area. At the end of the period shown, a rapid descent of the boundary layer top could be observed. On that day, the foehn did not reach the ground, but was only a few decameters above ground. It was a common observation that the decrease of the depth of the cold pool was a slower process than its rebuilding by advection.

\section{f. Three-dimensional gravity wave breaking}

Project P6 arose from the need to test the ability of the new generation of mesoscale numerical models to predict mountain wave generation and breaking. It is broadly felt that the remarkable progress of numerical models in the last few years in terms of spatial resolution, nesting, data assimilation, and nonhydrostatic formulation has outstripped our progress in testing the models against observations at the proper scale. During the SOP, mesoscale models were used in real time to guide mission design toward areas offering the best chances of encountering gravity wave breaking events. Measurements were taken by the Falcon (carrying the DIAL water vapor lidar), 
TWL Doppler lidar

Mesoscale Apline Program

29 october 1999 from 17:20:28 to 18:22:48 UTC

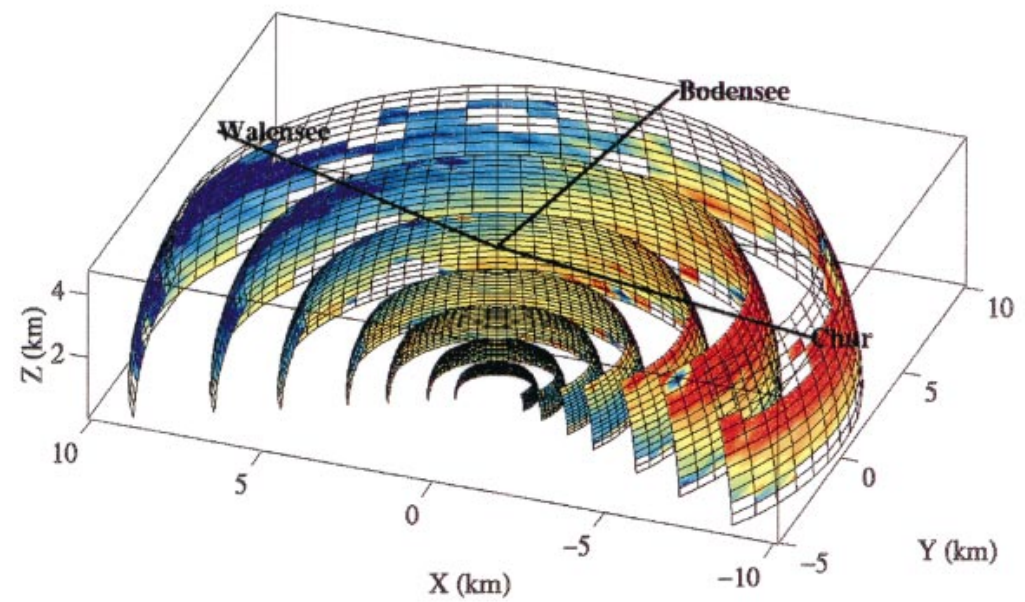

FIG. 13. Radial velocity field evaluated by the TWL Lidar at Vilters (Rhine valley). The raster scan was performed by sweeping the azimuth angle from $-98^{\circ}$ (or $262^{\circ}$ ) (in the direction of the Rhine valley toward Chur) to 142 degrees (in the direction of Seez valley toward Walensee), and the elevation from 4 to 28 degrees after an accumulation of 10 shots used to retrieve one radial velocity profile. With increments in elevation and azimuth of 2 and 5 degrees, respectively, each velocity estimate was spaced transversely about $105 \mathrm{~m}$ horizontally and $262 \mathrm{~m}$ vertically at 3-km range. Because the lidar is on the valley floor, this mode produces velocity estimates between portions of spherical surfaces along the valley axes and bounded laterally by the sidewalls (courtesy of P. Drobinski). investigated (see Table 5). These cases included various flow directions over large massifs within the Alpine regions. In each case, the aircraft were directed to the specific location for which the largest vertical velocities and lowest Richardson numbers were predicted by operational and research models. Generally, the flight tracks were designed to give repeated legs at the same altitude along a single line. This approach put highest priority on the issue of the wave's temporal evolution. In some cases, however, the aircraft shifted to a second altitude after a few legs and this change, together with the presence of other aircraft above or below, gave reasonable vertical coverage as well. Additional vertical coverage was provided by the dropsondes and downward-pointing airborne lidars.

Preliminary evaluation of these cases has indicated that two particular scientific issues may be critical for understanding the GWB data from MAP. First, the occurrence of cold air blocking and trapping in valleys seems to be playing the Electra (carrying the SABL lidar) and the C130. The Fokker (carrying the LEANDRE 2 lidar) also joined them on one occasion. Dropsondes from these aircraft were also used to document extensively the wind and stability. The models used in the flight planning included the MeteoSwiss model, the Eastern European Aladin model, the German (LM) model, the Canadian MC2 model, and the U.S. Navy (COAMPS) model.

According to model predictions, the best conditions for GWB in the Alps are strong winds from the west or from the east over the western Alps, or winds from the north or south over the major eastwest Alpine ridge. Unfortunately, these special conditions were not frequent during the MAP-SOP. The SOP was well endowed with events of southwest flow, giving good Wet-MAP and shallow foehn cases, but such flows run parallel to most of the primary Alpine ridges giving poor gravity waves. In spite of these conditions, 11 cases were identified and

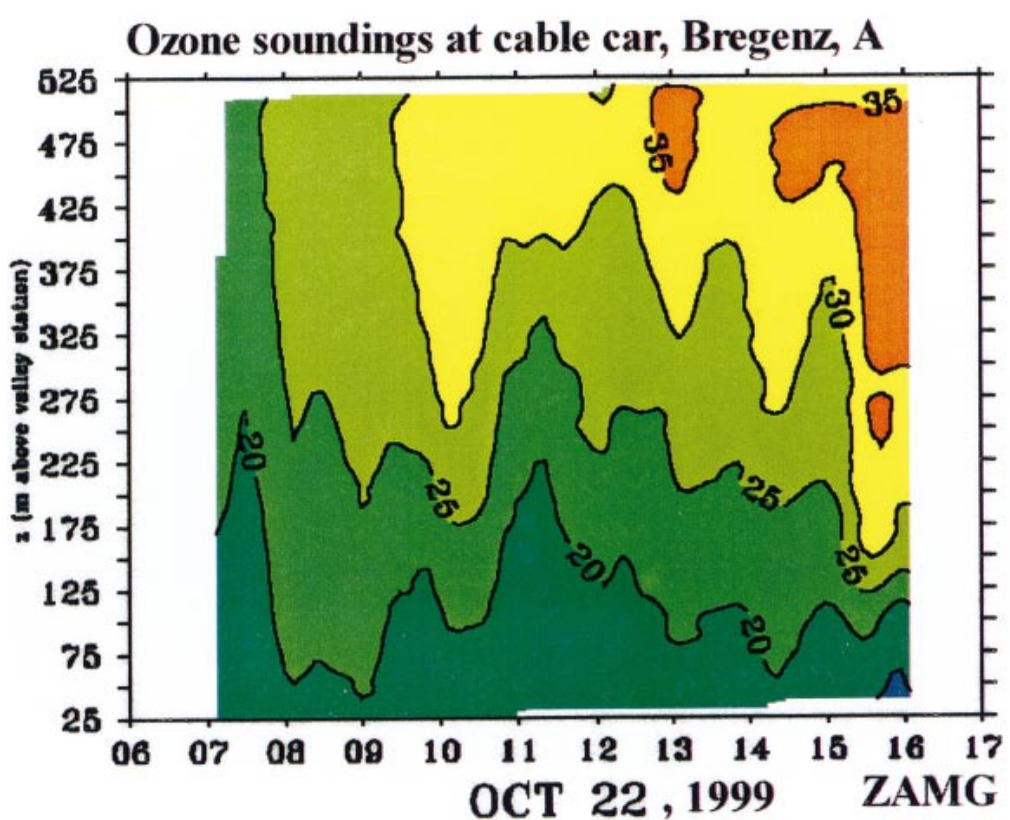

FIG. 14. Time-height cross section of the ozone concentration (ppb) on 22 Oct 1999. The data were acquired on a cable car from Bregenz to Pfaender Mountain, near Lake Constance. The time resolution corresponds to the frequency of the cable car, approximately 15 min (courtesy of K. Baumann). 
When a single peak stood up above the surrounding peaks and ridges, that peak would generate waves while the other would not, immersed as they were in a stagnant blocked layer. A good example of this behavior was the Mont Blanc case on 2 November. A stagnant layer topped by a sharp shear layer extended to an altitude of about $3500 \mathrm{~m}$. Only Mont Blanc, reaching to $4808 \mathrm{~m}$, penetrated well into the strong airstream above, generating vertically propagating mountain waves. Monte Rosa may have done this same thing on 8 November. (ii) When several ridges lie across the flow, only the last and highest in the sequence will generate mountain waves, due to the trapped air in valleys upstream. The Hohe Tauern in the eastern Alps gave good examples of this phenomenon during southerly flow. On 25 October, the downlooking DIAL lidar on the Falcon discovered a spectacular pattern of mountain wave clouds in this region, including the arching wave cloud near the stratosphere.

The second recurring pattern was the generation of trapped lee waves, often missed by the model predictions. It has been speculated previously that nonlinear processes can transfer wave energy from vertically propagating waves to periodic lee waves. A good example was the southerly flow event on 30 September. The models predicted a deep mountain wave over the Hohe Tauern with strong descent. The Electra found some evidence of the strong descent but a clear periodic lee wave was detected as well. The models differed on their prediction of the lee wave. A second example was on 8 November. With strong

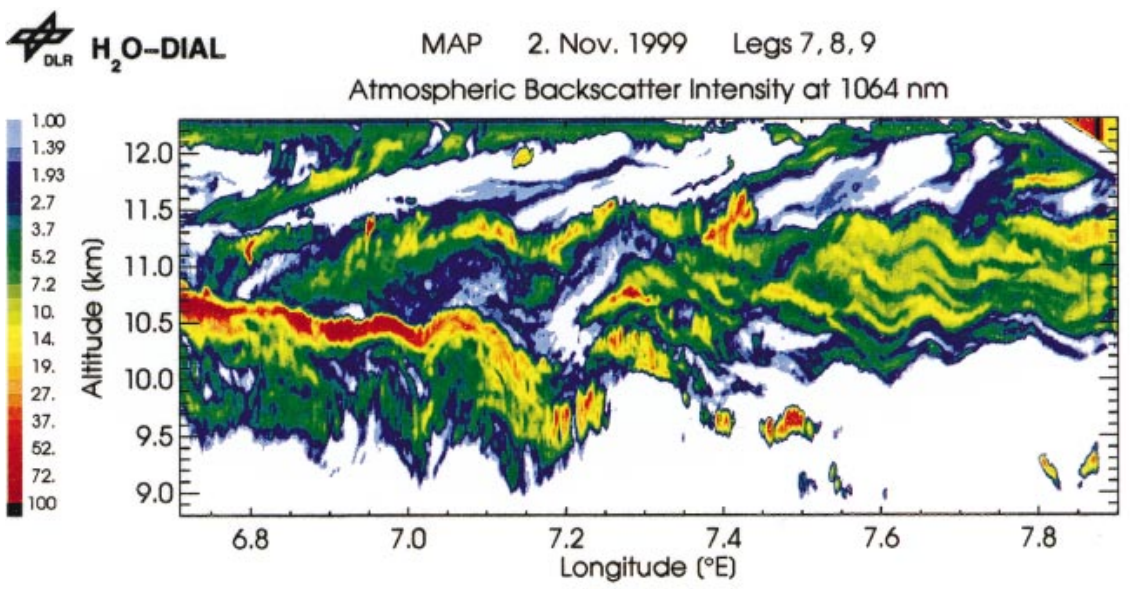

FIG. 15. Wave structures within a cirrus layer above and downstream of Mont Blanc $\left(6.85^{\circ} \mathrm{E}\right)$ visualized by airborne backscatter DIAL data from $12.5-\mathrm{km}$ altitude. The northeast (right) to southwest (left) straight flight segment covers $145 \mathrm{~km}$ and was executed against the ambient wind between 1102 and 1116 UTC on 2 Nov (courtesy of C. Kiemle). northerly flow, the airstream above the Alps was found to be nearly undisturbed while the airstream through the major passes gave strong descent and clearing. At the boundary region between the two streams, satellite images and in situ aircraft data showed periodic lee waves. On 13 November, while the disturbance at flight level was judged to be weak, the SABL found strong periodic lee waves expressed in the cloud layer below. On the Mont Blanc case (2 November), the Falcon found lee waves at its highest flight level (see Fig. 15), perhaps generated by nonlinearity in the vertically propagating waves when they reach the stratosphere.

\section{g. Potential vorticity banners}

The idea that gravity wave breaking above mountains or surface friction on mountain slopes could alter the PV in a stratified atmosphere was put forward about 10 years ago. The PV generated near mountains, being a quasi-conserved quantity, would then drift downstream forming strips or banners. In simple terms, the issue is whether the mountains produce a wake of some considerable extent. Some verification of the idea is available from numerical simulations and from small field experiments and satellite images near mountainous islands (e.g., Hawaii, St. Vincent, and the Aleutians). The goal of a PV banner project in MAP was to see whether the banners could be observed and understood in complex terrain such as the Alps and whether model predictions of banners were believable. A particular question was whether the banners would have a single well-defined scale, or whether the downstream region would be full of chaotic disturbances of all scales. After all, the mountains themselves have a multitude of physical scales.

Project P7 had four research aircraft available for missions around the Alps. The Electra was equipped with flight-level instruments, dropsondes, the SABL lidar, and the Eldora tail doppler radar. The P-3 had flight level instruments, dropsondes, and a tail Doppler radar. The Fokker and Merlin both carried flight level instrumentation. In addition the Fokker was equipped with the down-looking LEANDRE 2 lidar. 

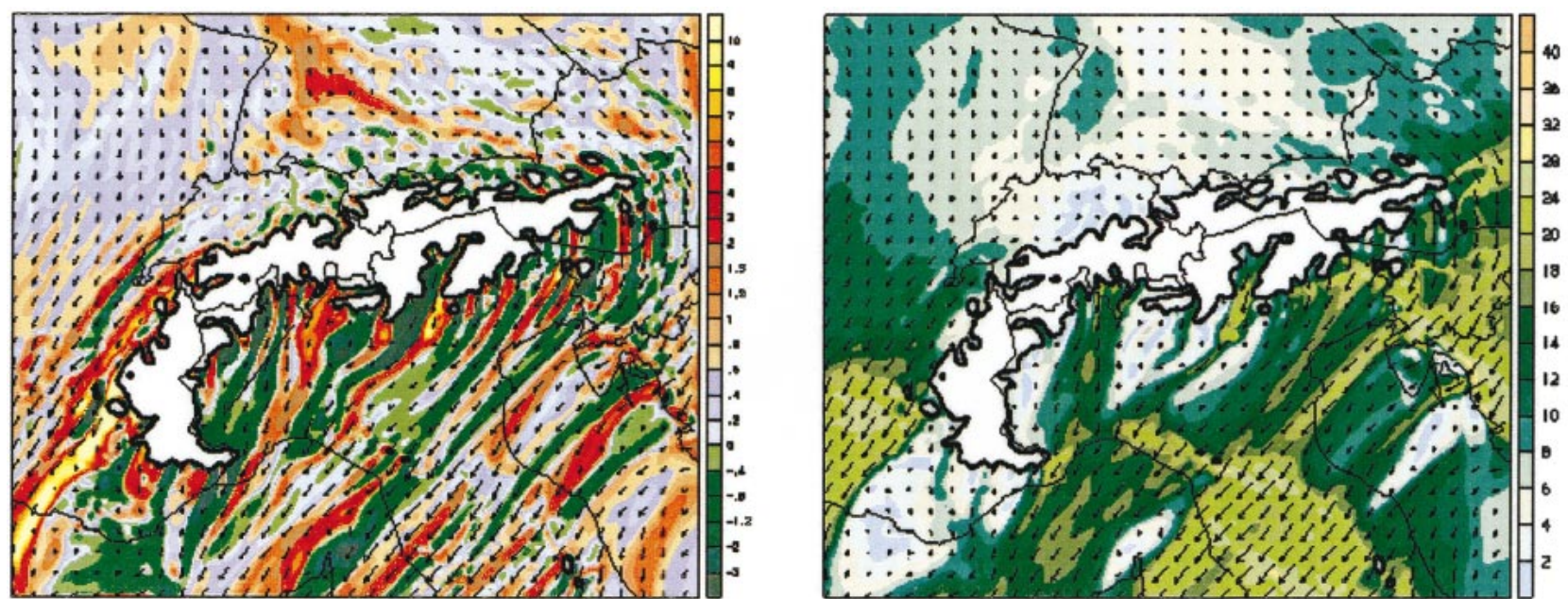

FIG. 16. MC2 numerical simulation results for IOP15, 8 Nov, 1500 UTC (18 h after model initialization). The panels show the 850-hPa distribution of (left) potential vorticity in PV units and (right) wind vectors and wind speed in $\mathrm{m} \mathrm{s}^{-1}$ on the $850-\mathrm{hPa}$ level. The PV banners present are associated with three Alpine wind systems, namely an atypical mistral (to the southwest of the Alps), north foehn through the Gotthard and Brenner Passes (over the Po valley) and bora (over the Adriatic Sea; courtesy of C. Schär and R. Benoit).

A useful distinction in the flight track design phase was between the primary banners coming from the eastern and western ends of the Alps and the secondary banners in between coming from individual peaks along the irregular Alpine ridge line. The primary banner was expected to be well defined, because on the western side, it coincides with the shear zone terminating famous mistral wind (a strong northerly flow off the French Riviera, originating in the Rhone valley). The secondary banners were expected to be more difficult to identify.

Successful missions were conducted during the SOP on six good cases (see Table 5). Four of these cases came during IOP 15 , associated with a classic cold front/lee cyclogenesis event in early November. The two mistral cases, 1 October and 6 November, developed in the usual way. Northwesterly flow, following a cold front, was split by the Alps and channeled between the Pyrenees and the western Alps. The two cases were investigated using very similar flight track strategies. The Electra and P-3 flew from Innsbruck southwest through the Milan area to a reference point over the Ligurian Sea between Genoa and Corsica. As part of this "ferry" flight, the flight tracks were modified to pass through secondary PV banners from Monte Rosa. After reaching the reference point, repeated legs to the southwest at various altitudes were flown through the eastern shear line of the mistral. Frequent dropsonde releases and the down-looking lidar helped to further define the complicated vertical structure of the shear zone. In the 6 November case, the Fokker and Merlin joined the survey, significantly improving the observing density. Both cases had strong, well-defined shear zones.

On 7 November, a bora (a strong northeasterly wind on the Adriatic Sea, off the Croatian coast) could be documented. This case was unusually strong; perhaps one of the strongest boras in the last decade. The P-3 performed a survey some distance offshore, parallel to the coast, while the Electra flew closer to the coastal range of the Dinaric Alps. In this way, the downstream evolution of the PV banners could be ascertained. The Electra also flew a few legs along the bora flow, across the coastal range, detecting strong turbulence and collecting interesting observations in the cold air layer beneath the aircraft using the SABL lidar.

The northerly flow event on 8 November was well surveyed with research aircraft. The wealth of PV banners forecast by MC2 on this case is shown in Fig. 16. On that day the P-3, Fokker, and Merlin flew an eastwest cross section south of the Alps. They found two broad stable northerly jets, associated with the flow through the two main gaps in the Alpine ridge (the Gotthard and Brenner Passes), and therefore confirming the model simulation. Flights by the Fokker and Merlin on the following day (9 November) showed the same jets but with weaker amplitude.

\section{h. Structure of the planetary boundary layer over steep orography}

The observational strategy for P8 relied on a mixture of surface-based and airborne measurements, taken in the "Riviera" section of the Ticino valley (see 

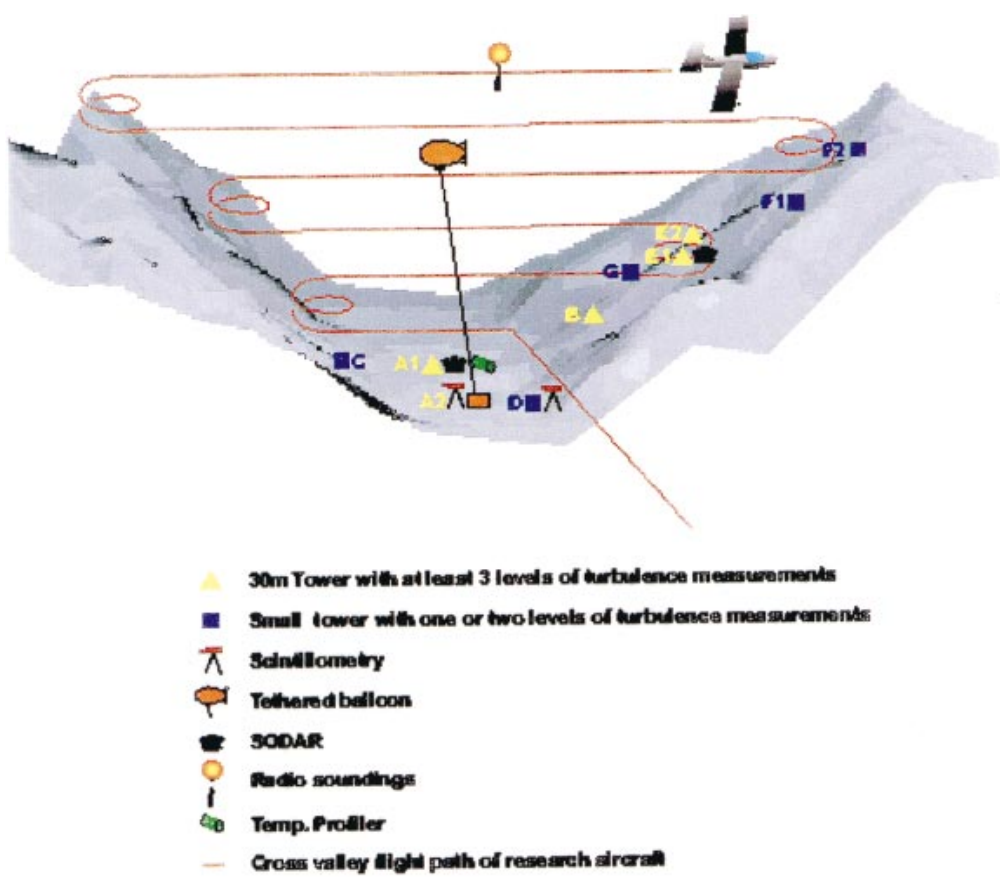

FIG. 17. A sketch of the instrumentation in the Riviera valley during the SOP (courtesy of M. Rotach).

Fig. 17). A series of towers installed across the valley floor documented the flow at various levels up to $30 \mathrm{~m}$ above the ground, along with sodars and a microwave temperature profiler. Turbulent fluxes were deduced from scintillometers and 20 sonic anemometers. High temporal resolution measurements at low altitude with the Dimona light research aircraft, a tethered balloon, and a radio sounding system were also performed. On one occasion (29 September) the DOW radar realized measurements inside the Riviera. PBL-related investigations were also carried out in the Rhine valley with similar instrumentation.

Research flights with the light research aircraft were carried out on eight days in August and September. On four days the development of the valley atmosphere was convectively dominated (three of them prior to the official SOP). On two days the forcing for the turbulence was clearly of mechanical nature. The two days following the heavy precipitation event of IOP 3 were used to investigate the mixed convectivemechanically driven boundary layer and the transition from a convective to a convective-mechanical forcing of the turbulence structure. Weather conditions and data collection were excellent on at least four days.

The outstanding feature of P8 was the extraordinarily dense and complete instrumental setup for turbulence measurements. This will allow questions of spatial inhomogeneity and slope effects to be investigated in much more detail than in former studies. It will be possible to reconstruct a three-dimensional turbulence structure information for the valley, using vertically stacked and horizontally staggered tracks by the airplane along and across the instrumented cross section. Because flights were carried out in the morning and in the afternoon of most days, the diurnal evolution of the valley boundary layer can be explored as well.

The unprecedented number of instruments, in particular the 20 sonic anemometers and the 2 scintillometers in the valley transect along with the aircraft data, will allow an investigation of the turbulent exchange processes in steep topography and the exchange processes between the valley atmosphere and the free atmosphere above. There were occasions with surprisingly little interaction between the valley atmosphere and the lower troposphere above. For example, on days with strong synoptic forcing above crest height there can be almost no wind in the valley below.

Boundary layer measurements were also taken in the LMTA, mainly over the Po valley close to the Alpine foothills, in coordination with those in the Riviera valley (section 3a) and in the Rhine valley (section 3e).

\section{Outlook}

Additional information including reports and quick look plots are available to anyone through the Joint Office for Science Support (JOSS) Field Data Catalog, produced during the SOP. A CD-ROM has been prepared by JOSS and the MDC to allow easy access to this information. But the main source of data will be the MAP Data Center in Zurich. According to the MAP Data Policy agreed upon by all partners, all data from the SOP will be provided by the MAP Data Center on the basis of free and unrestricted access for noncommercial research and educational activities. This will, of course, require that all groups having acquired data during the SOP deliver these data to the MDC in an appropriate time frame, after quality control. During the coming months, most of the work will therefore be devoted to the collection of those data and their 
preparation in a proper format. Several datasets are already available from the MDC through the Internet (http://www.map.ethz.ch).

Despite the efforts of data producers to check the quality of the data, it is well known that format and measurement errors always remain, and a lot of time and energy can be lost if proper actions are not taken at the right time. Before the MAP-SOP, it was decided to delegate some of these actions to partners, on the basis of clear proposals and shared funding. The quality control of all surface network data was assigned to the University of Vienna, Austria, through their Data Quality for MAP (DAQUAMAP) Project (see Steinacker et al. 2000). Similar actions will be undertaken for upper air soundings and other datasets. The reanalysis of MAP IOPs by modern assimilation systems will be organized in a similar way. This is needed to provide all numerical modeling groups involved in MAP with the best possible large-scale description of the meteorological situation during MAP IOPs.

The advancement of the scientific achievements of MAP will continue to be reviewed in the annual MAP meetings, hosted alternatively by participating countries. Announcements will be posted regularly on the
MDC Internet site. It is also expected that a wealth of MAP results will be presented in all major mountain meteorology conferences for the next few years. A quarterly MAP newsletter will keep participants abreast of all developments.

The MAP-SOP demonstrated a high degree of synergy between the eight projects, and an unprecedented level of collaboration between modelers and experimentalists. Never before had so much information been exchanged in real time between alpine meteorologists. It will remain in our memories as a time of great expectations and achievements.

Acknowledgments. We are deeply indebted to many colleagues who contributed to this overview paper by providing texts, figures and all kinds of input. We kept the authorship of this paper small because there was no obvious criterion to decide who would best qualify in addition to a minimal, nationally balanced list of authors. A list of MAP PIs and officials is provided in the appendix, but many more were involved: all deserve our grateful thanks. A special mention is due for Thomas Gutermann, former director of MeteoSwiss, chairman of the MAP International Governing Panel, for his outstanding leadership in making MAP a reality. Special thanks also to François Gérard for agreeing to synchronize the EUCOS soundings with the MAP-SOP.

\section{Appendix: A list of Pls and officials during the MAP-SOP}

Name
Domenico Anfossi
Laurence Armi
Baldassare Bacchi
Robert Banta
Eszter Barthazy
Kathrin Baumann
Klaus Beheng
Bruno Benech
Robert Benoit
Heinz Berger
Peter Binder
Philippe Bougeault
Jean-Louis Brenguier
Adrian Broad
Reinhold Busen
Andrea Buzzi
Jean-Luc Caccia
Carlo Cacciamani
Carlo Capsoni
Claudio Cassardo
Serge Chauzy
Michel Chong

Affiliation
CNR
University of California
University of Brescia
NOAA
ETH
ZAMG
IMK
LA
AES
MeteoSwiss
MeteoSwiss
CNRM
CNRM
UKMO
DLR
CNR
LSEET
SMR-ER
CNR
University of Alessandria
LA
CNRM

\author{
Main contribution \\ P1, special sounding station Genova \\ P4, P-3, and Dornier missions, MST \\ P3 \\ $\mathrm{P} 4$, NOAA/ETL lidar \\ $\mathrm{P} 1, \mathrm{ETH}$ radar and disdrometers \\ P5, PBL in Rhine valley \\ P1, microphysics \\ P5, CVB and Merlin missions \\ MC2 numerical model, MST \\ P5, CVB and cameras, sodars \\ Operations director \\ Science director \\ In flight icing, Merlin missions \\ P6, C-130 missions, MST \\ P2, P6, meteorology on Falcon \\ $\mathrm{P} 1$, Italian coordination, MST \\ P2, P7, French wind profilers \\ Climatology \\ P1, Radar in Spino d'Adda \\ P8, PBL over Po valley, MST \\ $\mathrm{P} 1$, electricity \\ $\mathrm{P} 1$, Ronsard radar, dual-Doppler retrievals
}




\begin{tabular}{|c|c|c|}
\hline Fernandino Congeduti & CNR & $\mathrm{P} 1$, lidar in LMTA \\
\hline Alain Dabas & CNRM & P5, TWL lidar in Rhine valley \\
\hline Huw C. Davies & ETH & $\mathrm{P} 2, \mathrm{MST}$ \\
\hline Richard Dirks & UCAR & Operations director \\
\hline Manfred Dorninger & IMGW & P5, Lightning composite \\
\hline Eric Dörflinger & CNRS & GPS water vapor measurements in POC \\
\hline James D. Doyle & NRL & P6, COAMPS model, Electra missions \\
\hline Dale R. Durran & University of Washington & P4, Electra missions, MST \\
\hline Philippe Drobinski & LMD & P5, P8, TWL Lidar in Rhine valley \\
\hline Aimé Druilhet & LA & P8, Merlin missions \\
\hline Gerhard Ehret & DLR & P2, P6, H20-DIAL on Falcon \\
\hline Heinz Finkenzeller & DLR & Air traffic coordination \\
\hline Andreas Fix & DLR & P2, P6, H20-DIAL on Falcon \\
\hline Cyrille Flamant & SA & P1, P4, P5, P7, Fokker missions \\
\hline Pierre Flamant & LMD & P6, WIND lidar on Falcon, TWL \\
\hline David C. Fritts & CRA & P6, SABL lidar on Electra \\
\hline Guiseppe Frustaci & Italian Meteorological Service & POC director \\
\hline Markus Furger & PSI & P5, scintillometers in Rhine valley \\
\hline Nimal Gamage & UCAR & Field catalog \\
\hline Teodoro Georgiadis & CNR & P1, P8, PBL measurements LMTA \\
\hline Umberto Giostra & CNR & P8, PBL measurements in LMTA \\
\hline Eugenio Gorgucci & CNR & $\mathrm{P} 1$, radar in Montagnana \\
\hline Giovanni Graziani & JRC Ispra & P8, Riviera tracer experiment \\
\hline Vanda Grubišić & DRI & P7, Electra missions \\
\hline Sabine Göke & ETH & $\mathrm{P} 1$, microphysics \\
\hline Joachim Gurtz & ETH & P3, Riviera hydrology \\
\hline Christian Häberli & MeteoSwiss & $\begin{array}{l}\text { P5, Rhine valley coordination, military } \\
\text { soundings }\end{array}$ \\
\hline Martin Hagen & DLR & $\mathrm{P} 1$, Alpine radar composite \\
\hline Michael Hardesty & NOAA & P4, NOAA/ETL lidar \\
\hline Hans Hirter & ETH & MDC and network manager \\
\hline Klaus-Peter Hoinka & DLR & $\mathrm{P} 2$, Falcon missions, MST \\
\hline Robert Houze & University of Washington & $\begin{array}{l}\text { P1, S-Pol, POC science coordinator, } \\
\text { MST }\end{array}$ \\
\hline David P. Jorgensen & NOAA & P1, P-3 Missions, MST \\
\hline Jürg Joss & MeteoSwiss & P1, Monte-Lema radar \\
\hline Vladislav Klaus & CNRM & Wind profiler Lonate Pozzolo \\
\hline Nick Kouwen & University of Waterloo & $\begin{array}{l}\mathrm{P} 3 \text {, precipitation monitoring and flood } \\
\text { forecasting }\end{array}$ \\
\hline Joachim Kuettner & UCAR & P6, MST \\
\hline Vincenzo Levizzani & CNR & P1, P8, Meteosat rapid scans \\
\hline Martin Löffler-Mang & IMK & P1, vertical Doppler radar \\
\hline Piero Malguzzi & CNR & P1, MST \\
\hline Guiseppe Mastrantonio & CNR & P1, P8, PBL measurements LMTA \\
\hline Georg Mayr & University of Innsbruck & $\mathrm{P} 4$, Brenner Pass instrumentation, MST \\
\hline Jose Meitin & UCAR & POC operations coordinator \\
\hline Marilena Menziani & University of Modena & P3, soil moisture measurements \\
\hline Valentin Mitev & Obs Neuchatel & P5, lidar \\
\hline Stephen Mobbs & University of Leeds & $\mathrm{P} 4$, microbarographs \\
\hline Marco Monai & CSIM & $\mathrm{P} 1$, radars in northeastern Italy \\
\hline James Moore & UCAR & POC operations coordinator \\
\hline
\end{tabular}




\begin{tabular}{|c|c|c|}
\hline Louisa Nance & CIRES & $\mathrm{P} 4, \mathrm{P} 7, \mathrm{P}-3$ missions \\
\hline Simonetta Paloscia & CNR & $\begin{array}{l}\text { P3, microwave soil moisture } \\
\text { measurements }\end{array}$ \\
\hline Peter Parson & ZAMG & Head of MOC forecasting center \\
\hline Jacques Pelon & SA & P1, P4, P5, P7, Fokker missions \\
\hline Greg Poulos & CRA & P6, Electra missions \\
\hline Herbert Pümpel & Austrocontrol & MOC director \\
\hline F. Martin Ralph & NOAA & $\mathrm{P} 4, \mathrm{P} 7, \mathrm{P}-3$ missions \\
\hline Roberto Ranzi & University of Brescia & P3, hydrology coordinator \\
\hline Gabriele Rau & ZAMG & P5, STAAARTE investigator \\
\hline Oliver Reitebuch & DLR & P6, WIND lidar on Falcon \\
\hline Evelyne Richard & LA & P1, P5, modeling coordinator, MST \\
\hline Renzo Richiardone & University of Torino & P1, P6, microbarograph network LMTA \\
\hline Hans Richner & ETH & P5, FORM master coordinator \\
\hline Andrea Rossa & MeteoSwiss & Facility status coordinator \\
\hline Mathias Rotach & ETH & P8, Riviera coordinator \\
\hline Richard Rotunno & NCAR & P1, POC science coordinator, MST \\
\hline Frank Roux & LA & P1, Electra missions, MST \\
\hline Dominique Ruffieux & MeteoSwiss & P5, wind profilers Rhine valley \\
\hline Renato Santangelo & University of Modena & $\begin{array}{l}\text { P1, P4, P8 special sounding station } \\
\text { Verona }\end{array}$ \\
\hline Christoph Schär & ETH & P6, P7, Electra missions, MST \\
\hline Georges Scialom & CETP & $\mathrm{P} 1$, Ronsard radar \\
\hline Steven Skubis & Yale University & Facility status coordinator \\
\hline Ronald Smith & Yale University & Science director \\
\hline Bradley Smull & University of Washington & $\mathrm{P} 1$, DOW radar and $\mathrm{P}-3$ missions, $\mathrm{MST}$ \\
\hline Joel Stein & CNRM & P1, P5 Mesoscale modeling \\
\hline Douw Steyn & University of British Columbia & P8, Riviera PBL \\
\hline Ingo Steinacker & Innsbruck & Facility status coordinator \\
\hline Reinhold Steinacker & University of Vienna & P4, P5, MST, Austrian coordination \\
\hline Matthias Steiner & Princeton University & $\mathrm{P} 1, \mathrm{DOW}$ radar \\
\hline Joel Van Baelen & CNRM & $\mathrm{P} 2$, Wind profiler network \\
\hline Roland Vogt & University of Basle & P8, Riviera PBL \\
\hline Siegfried Vogt & IMK & P5, Wind profiler, RASS \\
\hline Hans Volkert & DLR & $\begin{array}{l}\text { P6, Falcon missions, German } \\
\text { coordination, MST }\end{array}$ \\
\hline Christian Werner & DLR & WIND lidar \\
\hline Charles D. Whiteman & PNNL & P4, Surface logger network \\
\hline Jim Wilson & NCAR & P1, S-Pol operations \\
\hline Volkmar Wirth & University of München & $\mathrm{P} 2$, Falcon missions \\
\hline Joshua Wurman & University of Oklahoma & P1, DOW operations \\
\hline
\end{tabular}

\section{References}

Barthazy, E., S. Goeke, Z. Zeng, J. Vivekanandan, and S. M. Ellis, 2000: Comparison of two hydrometeor identification algorithms of the S-Pol radar with in-situ measurements of hydrometeors on a mountain. Preprints, 13th Int. Conf. on Clouds and Precipitation, Reno, NV, Int. Commission on Clouds and Precipitation, 292-295.

Binder, P., and C. Schär, Eds., 1996: MAP design proposal. MeteoSwiss, 75 pp. [Available from the MAP Programme Office, MeteoSwiss, CH-8044, Zurich, Switzerland.]

— [Available from MAP Programme Office, MeteoSwiss, CH-8044, Zurich, Switzerland.]

Bougeault, P., B. Benech, P. Bessemoulin, B. Carissimo, A. Jansa, J. Pelon, M. Petitdidier, and E. Richard, 1997: PYREX: A summary of findings. Bull. Amer. Meteor. Soc., 78, 637-650. 
—, P. Binder, and J. Kuettner, Eds., 1998: MAP science plan. MeteoSwiss, 64 pp. [Available from MAP Programme Office, MeteoSwiss, CH-8044, Zurich, Switzerland.]

Chong, M., and Coauthors, 2000: Real-time wind synthesis from Doppler radar observations during the Mesoscale Alpine Programme. Bull. Amer. Meteor. Soc., 81, 2953-2962.

Drobinski, P., A. M. Dabas, and P. H. Flamant, 2000: Remote measurement of turbulent wind spectra by heterodyne Doppler lidar technique. J. Appl. Meteor., 39, 2434-2451.

Ehret, G., K. P. Hoinka, J. Stein, A. Fix, C. Kiemle, and G. Poberaj, 1999: Low stratospheric water vapor measured by an airborne DIAL. J. Geophys. Res., 104 (24 D), 31 351-31 359.

Flamant, C., and Coauthors, 2000: Airborne lidar measurements of aerosol spatial distribution and optical properties over the Atlantic Ocean during a European pollution outbreak of ACE2. Tellus, in press.

Kuettner, J. P., 1986: The aim and conduct of ALPEX. Scientific Results of the Alpine Experiment, GARP Publications Series No. 27, WMO/TD 108, 3-14.

Levizzani, V., 1998: METEOSAT rapid scan during MAP-SOP. MAP Newsl., 8, 17-19. [Available from MAP Programme Office, MeteoSwiss, CH-8044, Zurich, Switzerland.]
Steinacker, R., C. Häberli, and W. Pöttschacher, 2000: A transparent method for the analysis and quality evaluation of irregularly distributed and noisy observational data. Mon. Wea. Rev., 128, 2303-2316.

Vivekanandan, J., D. S. Zrnic, S. M. Ellis, R. Oye, A. V. Ryzhkov, and J. Straka, 1999: Cloud microphysics retrieval using S-band dual-polarization radar measurements. Bull. Amer. Meteor. Soc., 80, 381-388.

Vogt, S., K. Baumann, C. Haeberli, M. Piringer, and D. Ruffieux, 2000: The use of tropospheric profiling in describing Foehn events during the MAP field experiment. Fifth Int. Symp. on Tropospheric Profiling, Adelaide, Australia, University of Adelaide, 49-51.

Wurman, J., J. Straka, E. Rasmussen, M. Randall, and A. Zahrai, 1997: Design and deployment of a portable pencil-beam pulsed Doppler 3-cm radar. J. Atmos. Oceanic Technol., 14, 1502 1512.

Zeng, Z., 1999: Methodology for the identification of precipitation type by polarimetric radar. M.S. thesis, Dept. of Meteorology, University of Washington, Seattle, WA, 153 pp.

With the development of meteorological science and the continual refinement of the technologies used in its practical application, the need to produce a new edition of the International Meteorological Vocabulary (IMV) became evident (the original edition was published in 1966). This volume is made up of a multilingual list of over 3500 terms arranged in English alphabetical order, accompanied by definitions in each of the languages (English, French, Russian, and Spanish) and an index for each language. This new edition has been augmented with numerous concepts relating to new meteorological knowledge, techniques, and concerns. It should help to standardize the terminology used in this field, facilitate communication between specialists speaking different languages, and aid translators in their work.

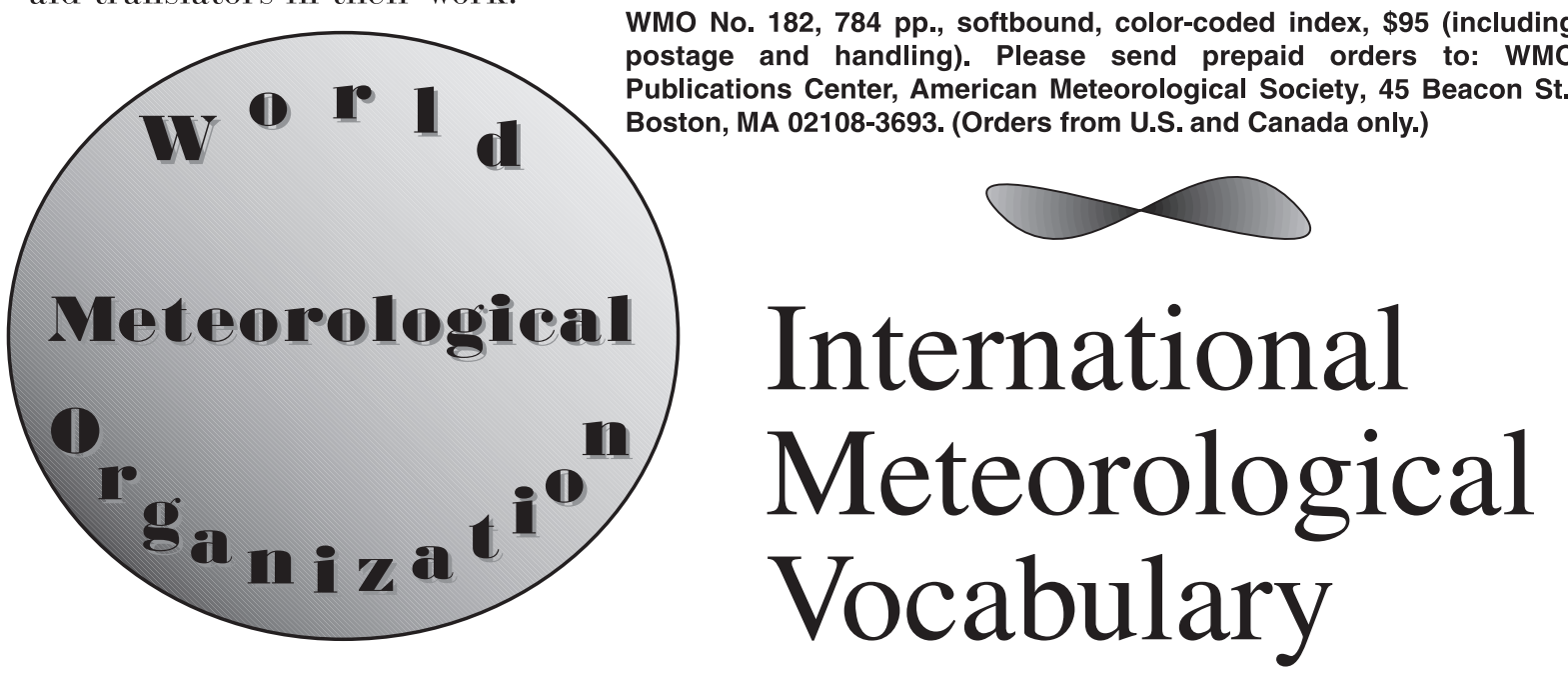

